
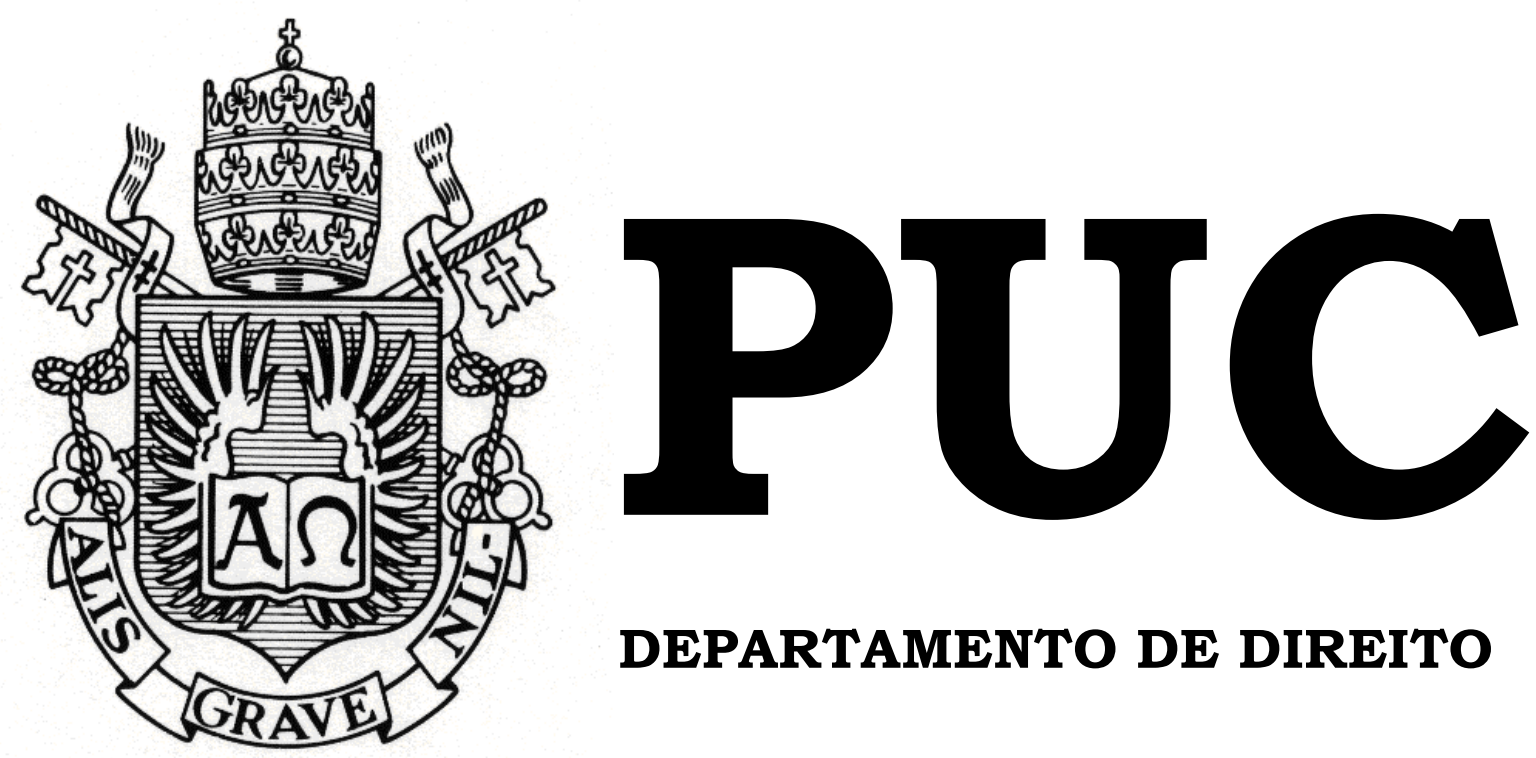

DEPARTAMENTO DE DIREITO

\title{
A INFLUÊNCIA DA CONSTITUIÇÃO CIDADÃ NOS NOVOS PARADIGMAS FAMILIARES
}

Por

LUAN MOREIRA DA FONSECA CARNEVALE

ORIENTADOR: Ana Paula Santoro

CO-ORIENTADORA: Inês Alegria Rocumback

\section{2}

PONTIFÍCIA UNIVERSIDADE CATÓLICA DO RIO DE JANEIRO

RUA MARQUÊS DE SÃO VICENTE, 225 - CEP 22451-900

RIO DE JANEIRO - BRASIL 


\title{
A INFLUÊNCIA DA CONSTITUIÇÃO CIDADÃ NOS NOVOS PARADIGMAS FAMILIARES
}

por

\section{LUAN MOREIRA DA FONSECA CARNEVALE}

\author{
Monografia apresentada ao \\ Departamento de Direito da \\ Pontifícia Universidade Católica do \\ Rio de Janeiro (PUC-Rio) para a \\ obtenção do Título de Bacharel em \\ Direito.
}

Orientadora: Ana Paula Santoro Co-Orientadora: Inês Alegria Rocumback 


\section{AGRADECIMENTOS}

Primeiramente, à minha mãe, por todo o zelo e todos os cuidados, desde o ventre até os dias atuais; pelas palavras de conforto e incentivo; pelo colo ao qual sempre posso recorrer.

Ao meu pai, sempre encorajador das minhas decisões, por quem tenho imenso respeito, não obstante as múltiplas diferenças.

Ao Santo Agostinho, responsável por minha formação de base, que sempre buscou me ensinar, embora muitas vezes eu relutasse em não querer aprender

À Pontifícia Universidade Católica, que, além de ter sido meu lar nos últimos 5 anos, me ofereceu todas as condições técnicas e orçamentárias para concluir este curso.

Aos meus queridos professores, com os quais pude absorver não só lições jurídicas, mas sobretudo humanas. Ao ilustre Dr. Firly Nascimento Filho e suas assacadilhas perspicazes. Ao grande Marcelo Calixto, exemplo de humildade e humanidade. Ao amigo Bruno Vaz, que apesar das tendências futebolísticas, tem minha imensa admiração. Ao sempre atencioso e parceiro Breno Meralagno. À queridíssima Flávia Limmer, sempre solícita e compreensiva, meu carinho sincero.

À minha orientadora Inês Alegria, com quem tive a honra de conviver em Direito de Família, Direito da Criança e do Adolescente, Estágio Supervisionado IV, até chegar a esta monografia. Meus agradecimentos por todos os momentos de compreensão, atenção e carinho. O mundo certamente seria um lugar muito melhor se houvesse outras Inês entre nós. Fica aqui registrada minha gratidão e minha admiração. Obrigado por tudo! 
Ao meu primeiro amigo Jorginho Maffei, com quem conservo uma amizade de quase duas décadas. A esse grande guerreiro responsável por me ensinar que nunca podemos deixar de acreditar na vida.

À nobre caravana vascaína que me acompanha em cada jornada do nosso amado clube. Melhor que ser Vasco é ser Vasco com vocês. Casaca!

Aos meus amigos Lucas Abbade, Lucas Xavier, Lucas Costa, Lucas Fleming, Lucas Pupp, Leonardo Dionysio, Lucas Leitão, Luiz Felipe Barbosa, Lucas Ian Canellas, Luiz Felipe Gonzales, Luis Felipe Dentin, que me acompanham desde os primeiros passos acadêmicos, iniciados no Santo Agostinho. Levarei vocês comigo para sempre. Faltam palavras, meus amigos.

À maravilhosa e única Louise Schmitt, companheira e fiel amiga desde meus oito anos.

Aos também inesquecíveis parceiros agostinianos, que me carregam no colo até hoje - Rafael Almeida, Paulo Nahar, Raphael Fernandes, Pedro Chaves, Rodrigo Fraga, Michael Gaia.

Aos insubstituíveis Fernando Papa e Felipe Rozenberg, que trio! À saudosa legião de Copacabana - Daniel Caliman, Daniel Carvalho, Daniel Correa, Breno Machado, Alexandre Berriel, por tudo que vivemos.

Ao querido Pedro Seixas, pelos 10 anos de colégio e 5 de faculdade. Com certeza muitos ainda estão por vir.

Ao meu grande irmão Jullian Balt, sempre presente, meu ídolo, que me ensinou ser preciso saber lutar sozinho, embora nunca tenha me deixado desamparado.

À Julia Moraes, por todos os anos juntos, por toda parceria, pelo coração gigante e pela generosidade de sempre.

À Isabela Cury, pelos anos de verdadeira e recheada irmandade, por estar sempre disponível, pela Disney, pelas palavras sábias. Minha gigante em apenas um metro e meio! 
À ilustre cidade de Resende, por ter me presenteado com a Luiza Trindade e a Rayani Costa, sem as quais, certamente, minha vida não seria tão alegre e irreverente. E de fato amizades de infância se formam depois $\operatorname{dos} 20$ anos!

Aos meus fieis escudeiros, agregados ao time durante a vida universitária, Felipe Sales, Dylmar Netto (Imenso), Gustavo Rodrigues (Topin), Matheus Macedo (Soldado) e Matheus Vaz, por todas as missões nas quais nos aventuramos, por serem não só companheiros na boa, mas sobretudo nas ruins. Verdadeira família! Para sempre Sistema!

Aos amigos do sempre charmoso Arpoador - Omar Farhat, Gustavo Contreiras, Lucas Pimentel, Paulo Carvalho, Murilo Nascimento, Isaac Oliveira, Henrique Pimentel, Hugo Gelbert, com quem tanto aprendi e cresci. A rua ensina bastante!

Ao meu eterno amigo Matthaus de Souza, por quem tanto torço e a quem procuro servir de exemplo. Toda a luz a você, meu irmão. Vamos juntos sempre!

À especial turma da qual fiz parte na faculdade, obrigado por todos os anos de convívio. Cada momento valeu uma vida. Para sempre HB!

Por fim, aos meus avós, em nome dos quais busco a cada dia ser uma pessoa melhor. Obrigado por tudo! 


\section{RESUMO}

CARNEVALE, Luan Moreira da Fonseca. A Influência da Constituição Cidadã nos Novos Paradigmas Familiares. Rio de Janeiro: 2017: 77 p. Monografia de final de curso. Departamento de Direito da Pontifícia Universidade Católica do Rio de Janeiro - PUC-Rio.

O advento da Carta Magna de 1988 marca a transição do regime autoritário para o democrático, respaldado por um texto consagrador de inúmeros direitos e garantias, os quais foram frutos de uma heterogênea Assembleia Constituinte, que contou com a participação de diversos setores da sociedade. Na seara do direito de família, destacam-se importantes consequências, com a passagem de uma ótica patrimonial para uma concepção mais humanitária, baseada no afeto e na dignidade da pessoa humana - pilares das entidades familiares. Entre as principais consequências, destacam-se igualdade dos gêneros em direitos e deveres (Art. $5^{\circ}, \mathrm{I}$ ), o princípio da afetividade, o tratamento indistinto entre todos os filhos (Art. $6^{\circ}, 227, \S 6^{\circ}$ ), a cristalização do princípio do melhor interesse da criança e do adolescente (Art. 227), o pluralismo, a dignidade da pessoa humana (art. $1^{\circ}$, III) e do princípio da solidariedade familiar (Arts. $3^{\circ}, 226$, 227 e 230). Através deste trabalho, busca-se apresentar as principais mudanças alavancadas pela Carta Magna de 1988, as quais estão cada vez mais voltadas a atender a complexidade das relações familiares, as novas demandas e a busca pela realização pessoal dos seus membros.

Palavras-Chave: Direito Constitucional - Constituição de 1988 Mutação Constitucional - Direito de Família - Princípios - Afetividade Igualdade - Liberdade- Dignidade da Pessoa Humana 


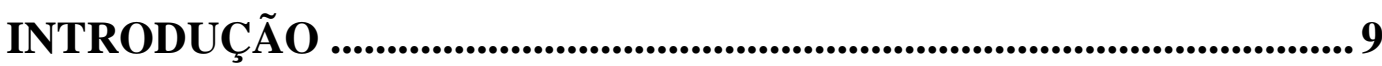

CAPÍTULO 1 - A CONCEPÇÃO DE FAMÍLIA ANTES DA CONSTITUIÇÃO FEDERAL DE 1988 .................................................... 11

1.1 A base normativa do Direito de Família antes da Constituição Cidadã 13

1.2 A relação conjugal pré Constituição de 1988 ……………………...... 15

1.3 A parentalidade antes da Constituição de 1988: o pátrio poder ......... 17

CAPÍTULO 2 - A FAMÍLIA NA CONSTITUIÇÃo CIDADÃ.............. 21

2.1 A constitucionalização do direito civil ............................................... 22

2.2 A parentalidade na CRFB/88: o pátrio poder e o poder familiar ...... 25

2.3. A dessacralização do casamento e as novas formas de surgimento do

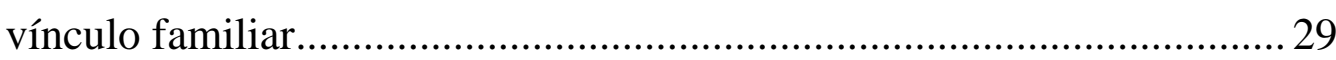

CAPÍTULO 3 - PRINCÍPIOS NORTEADORES DO DIREITO DE

FAMÍLIA _......................................................................................................... 34

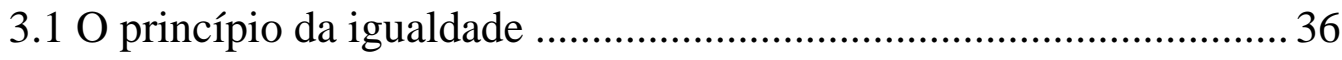

$3.2 \mathrm{O}$ princípio da dignidade da pessoa humana .......................................... 40

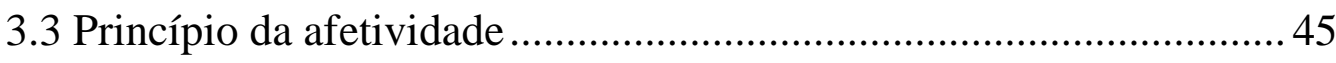

3.4 Princípio do melhor interesse da criança e do adolescente ................ 48

CAPÍTULO 4 - NOVAS FORMAS DE FAMÍLIA ..................................52

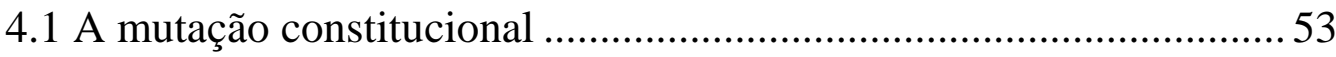

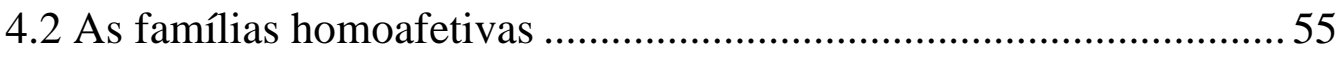

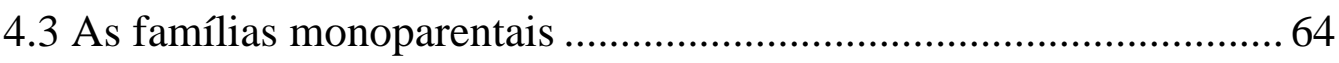

4.4 A pluriparentalidade e a vinculação socioafetiva................................. 66

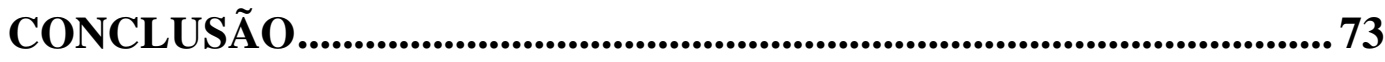

REFERÊNCIAS BIBLIOGRÁFICAS .................................................... 75 


\section{LISTA DE ABREVIAÇÕES}

\begin{tabular}{|c|c|}
\hline $\mathrm{AC}$ & - Ação Cautelar \\
\hline ADI & - Ação Direta de Inconstitucionalidade \\
\hline $\mathrm{ADPF}$ & - Arguição de Descumprimento de Preceito Fundamental \\
\hline Ag. & - Agravo \\
\hline $\mathrm{AgRg}$ & - Agravo Regimental \\
\hline AGU & - Advogado Geral da União \\
\hline Art. & - Artigo \\
\hline $\mathrm{C}$. & - Colendo \\
\hline $\mathrm{CC}$ & - Código Civil de 2002 \\
\hline $\mathrm{CC} / 16$ & - Código Civil de 1916 \\
\hline $\mathrm{CF}$ & - Constituição Federal \\
\hline Constituição & - Constituição Federal de 1988 \\
\hline $\mathrm{CF} / 88$ & - Constituição Federal de 1988 \\
\hline $\mathrm{CPC}$ & - Código de Processo Civil \\
\hline Des. & - Desembargador \\
\hline DF & - Distrito Federal \\
\hline E. & - Egrégio \\
\hline $\mathrm{EC}$ & - Emenda Constitucional \\
\hline Ed. & - Edição \\
\hline EDcl & - Embargos Declaratórios \\
\hline Exmo. & - Excelentíssimo \\
\hline fls. & - Folhas \\
\hline Ibid. & - Ibidem \\
\hline Min. & - Ministro \\
\hline $\mathrm{N}^{\mathrm{o}}$ & - Número \\
\hline p. & - Página \\
\hline
\end{tabular}




$\begin{array}{ll}\text { PUC-Rio } & - \text { Pontifícia Universidade Católica do Rio de Janeiro } \\ \text { RE } & - \text { Recurso Extraordinário } \\ \text { Rel. } & - \text { Relator } \\ \text { REsp } & - \text { Recurso Extraordinário } \\ \text { RJ } & - \text { Rio de Janeiro } \\ \text { RR } & - \text { Recurso de Revista } \\ \text { STF } & - \text { Supremo Tribunal Federal } \\ \text { STJ } & - \text { Superior Tribunal de Justiça } \\ \text { TRF } & - \text { Tribunal Regional Federal } \\ \text { TST } & - \text { Tribunal Superior do Trabalho } \\ \text { v. } & - \text { Volume } \\ \text { vol. } & - \text { Volume } \\ \S & - \text { Parágrafo }\end{array}$




\section{INTRODUÇÃO}

Os novos valores inseridos na Carta Magna de 1988 introduziram na ordem jurídica nacional um novo tratamento no que diz respeito ao instituto da família. No âmbito de um Estado Democrático de Direito, não há mais brechas para vedações discriminatórias no que toca à união, adoção e ao matrimônio e outras relações familiares antes tratadas como ilegítimas.

O presente trabalho não tem por escopo esgotar toda a matéria, tampouco elencar todas as novas modalidades de famílias, até por se tratar de audaciosa pretensão, tendo em vista a dinâmica das relações cotidianas. Busca-se, portanto, esmiuçar as principais inovações, no âmbito do Direito de Família, trazidas pela Constituição Federal de 1988.

No Capítulo I, é exposta a configuração do ordenamento jurídico antes da Constituição Federal de 1988, de forma que se pretende abordar relevantes questões tais como a visão patrimonialista e matrimonial, o tratamento distinto entre homens e mulheres. Por fim, aborda-se o pátrio poder, conceito que sofreu sensível transformação em razão dos princípios trazidos pela Constituição Federal de 1988, tendo em vista a família se tratar de um meio para realização de seus membros e não mais um fim em si mesma.

Já no Capítulo II, buscou-se abordar, inicialmente, a constitucionalização do Direito Civil, de modo que seus institutos devem ser examinados sob o prisma da Constituição Federal. Superada a hegemonia do Código Civil, a Carta Política de 1988 passa a ser o vetor através do qual devem ser interpretadas todas as normas do ordenamento jurídico pátrio.

São analisadas, ainda, a filiação e a consolidação do "poder familiar" em detrimento do pátrio poder, não mais caracterizado como um símbolo de 
autoridade masculina que obriga a subordinação do cônjuge e dos filhos ao chefe da família.

Nesse capítulo, abordam-se também as novas formas de surgimento do vínculo familiar, com destaque para a possibilidade da constituição de uma entidade familiar sem a necessidade do casamento, o qual era sacramento detentor do condão de elevar um agrupamento de pessoas ao status de família.

Por sua vez, no Capítulo III, são elencados os princípios norteadores do Direito de Família, estejam eles explícita ou implicitamente dispostos na Carta Política de 1988. Destacam-se os princípios da afetividade, do melhor interesse da criança, da igualdade, do pluralismo, da solidariedade e da dignidade da pessoa humana, com base nos quais deve se pautar a jurisprudência pátria.

A partir da análise de cada um dos princípios, pretende-se estabelecer uma conexão entre eles e o surgimento de novas formas de família, que são apresentadas no capítulo seguinte.

No capítulo IV, por fim, são apresentadas novas formas de família, sem o intuito de elencar um rol taxativo, tendo em vista a dinâmica realidade social. Ressaltam-se as famílias informais, homoafetivas, monoparentais e a pluriparentalidade.

Busca-se, no presente trabalho, expor as questões já decididas pelos Tribunais Superiores, as quais já são pacíficas e vinculam todo o poder judiciário.

Dessa forma, o escopo da presente obra é estabelecer uma análise crítica a respeito das principais mudanças constitucionais aplicadas ao Direito de Família, no contexto de um Estado Democrático de Direito. Para isso, traz-se um panorama do Direito Brasileiro anterior à Constituição de 1988 e outro posterior. 


\section{CAPÍTULO 1 - A CONCEPÇÃO DE FAMÍLIA ANTES DA CONSTITUIÇÃO FEDERAL DE 1988}

Segundo uma concepção biológica, a família pode ser compreendia como um conjunto de indivíduos que se originam de um tronco ancestral comum. A tutela jurídica em relação a tal instituto se baseava, tradicionalmente, nos efeitos sucessórios e patrimoniais.

Calcado em uma visão tradicionalista e religiosa, o ordenamento jurídico vigente trazia distinções vexatórias, ao estipular tratamento desigual aos filhos, em função de sua concepção ter se dado na constância ou não de uma relação conjugal cristalizada pelo casamento.

Contudo, tal visão, analisada sob o prisma do atual ordenamento jurídico e do desenvolvimento do conceito de família, se mostra veementemente anacrônica. Nessa linha, enuncia Caio Mário da Silva Pereira:

No desenvolvimento, ainda, do conceito de família, não mais comporta a classificação, que se ligava mais intimamente à qualificação dos filhos, e, por metonímia, distinguia a família 'legítima', que tinha por base o casamento; a 'ilegítima', originária de relações extrapatrimoniais; e a adotiva, criada pelas relações oriundas da adoção tradicional, pela legitimação adotiva que vigorou até 1990. Com a equiparação dos filhos adotada pela Carta Magna de 1988, inclusive dos adotados, proibiu-se, expressamente, designações discriminatórias relativas à filiação. ${ }^{1}$

Modernamente, tanto a legislação como a jurisprudência pátria têm a preocupação de, paulatinamente, promover aceitação de novos modelos de família, tendo em vista a dinâmica das situações fáticas percebidas na sociedade contemporânea. Priorizam-se, dessa forma, o cuidado, a afetividade e a solidariedade. Nesse sentido, enuncia o artigo 25 do Estatuto da Criança e do Adolescente:

\footnotetext{
${ }^{1}$ PEREIRA, Caio Mário da Silva. Instituições de Direito Civil. Rio de Janeiro: Forense, 2013. p. 26.
} 
Art. 25. Entende-se por família natural a comunidade formada pelos pais ou qualquer deles e seus descendentes.

Parágrafo único. Entende-se por família extensa ou ampliada aquela que se estende para além da unidade pais e filhos ou da unidade do casal, formada por parentes próximos com os quais a criança ou adolescente convive e mantém vínculos de afinidade e afetividade. ${ }^{2}$

A Constituição Cidadã foi responsável por inserir inúmeras inovações no que toca ao direito de família. Antes do advento da Carta Magna, a família era tida como uma instituição patriarcal, baseada em um modelo adotado pela legislação brasileira desde o período colonial até boa parte do século XX, com preocupações essencialmente patrimoniais.

Todavia, a família, outrora baseada no casamento, no poder autoritário de seu chefe e nas relações patrimoniais, recebeu distinto tratamento pela Constituição Federal de 1988. Destacam-se como principais pilares a dignidade da pessoa humana, o afeto, a solidariedade e o respeito entre seus membros.

A família não é tida como um fim em si mesma, mas sim como caminho mediante o qual seus componentes podem melhor buscar a realização pessoal. Nesse sentido, eis a lição de Caio Mário da Silva Pereira:

Nova estrutura jurídica se constrói em torno do conceito de família socioafetiva, à qual alguns autores identificam como 'família sociológica', onde se identificam, sobretudo, os laços afetivos, solidariedade entre os membros que a compõem, família em que os pais assumem integralmente a educação e a proteção de uma criança, que independe de algum vínculo jurídico ou biológico entre eles. Assim é que se tem, hoje, considerado a relação afetiva estabelecida entre os membros da família, podendo, muitas vezes, haver a priorização deste vínculo em detrimento do fator puramente biológico.

A 'despatrimonialização' do Direito Civil como 'uma tendência normativacultural' atinge também o Direito de Família não mais orientado na 'expulsão e redução quantitativa do conteúdo patrimonial', mas na tutela qualificativa das relações familiares. Sob esta perspectiva, destaca-se a orientação no sentido de

\footnotetext{
${ }^{2}$ BRASIL. [Estatuto da criança e do adolescente (1990)]. Estatuto da criança e do adolescente : lei n. 8.069, de 13 de julho de 1990, e legislação correlata [recurso eletrônico]. - 9. ed. - Brasília : Câmara dos Deputados, Edições Câmara, 2010. 207 p. - (Série legislação ; n. 83).
} 
identificar a família centrada na dignidade da pessoa humana e na solidariedade social. $^{3}$

\subsection{A base normativa do Direito de Família antes da Constituição Cidadã}

Até a Constituição de 1988, o Direito de família era essencialmente baseado no Código Civil de 1916. Dessa forma, predomina, à época, uma visão majoritariamente patrimonialista, cujo fito era a regulação do regime de bens no casamento e das questões sucessórias oriundas dos vínculos familiares.

Além disso, a figura do chefe de família gozava de hierarquia, em relação à qual os demais membros ficavam subordinados. Atualmente, foi superada tal concepção, de modo que a família é encarada com um agrupamento de indivíduos baseado na colaboração, na coordenação de projetos, no afeto.

Superou-se, assim, uma ótica centrada na autoridade para uma orientação democrático-afetiva, com fulcro na compreensão e no amor. Os laços de afetividade figuram na esfera jurídica como a força motriz das relações familiares. Logo, tem-se o afeto como marca que distingue a entidade familiar.

Nas palavras de Maria Berenice Dias:

O formato hierárquico da família cedeu lugar à sua democratização, e as relações são muito mais de igualde e respeito mútuo. $\mathrm{O}$ traço fundamental é a lealdade. Talvez não mais existam razões, quer morais, religiosas, políticas físicas ou naturais, que justifiquem esta verdadeira estatização do afeto, excessiva e indevida ingerência na vida das pessoas. $O$ grande problema reside em se encontrar, na estrutura formalista do sistema jurídico, a forma de proteger sem sufocar e de regular sem engessar.

É preciso demarcar o limite de intervenção do direito na organização familiar para que as normas estabelecidas não interfiram em prejuízo da liberdade do 'ser' sujeito. (...) Compreender a evolução do direito das famílias deve ter como premissa a construção e a aplicação de uma nova cultura jurídica, que permita

\footnotetext{
${ }^{3}$ PEREIRA, 2013, p. 27.
} 
conhecer a proposta de proteção às entidades familiais, estabelecendo um processo de repersonalização dessas relações, devendo centrar-se na manutenção do afeto, sua maior preocupação. ${ }^{4}$

Sob a égide do Código Civil de 1916, o matrimônio era o único meio válido capaz de dar origem a uma entidade familiar. Desse modo, a união entre uma mulher e um homem, sem o revestimento oficial exigido pelo instituto do casamento, era considerada concubinato, equiparado, até então, a uma sociedade de fato, de forma que não recebia regulação pelo Direito de Família. Verifica-se, assim, verdadeiro conservadorismo na legislação então vigente.

Compreendido como um instituto sagrado, o casamento possuía a marca da indissolubilidade, sendo reprodução de uma sociedade marcada pelo conservadorismo e tradicionalismo. Não bastasse a retrógrada concepção do casamento, que representava a única via capaz de dar ensejo a uma família, o Código Civil de 1916 enunciava inúmeras distinções entre os membros da família - seja entre o homem e mulher, seja entre os filhos oriundos de outros tipos de relacionamentos.

Nesse esteio, eis as lições de Maria Berenice Dias:

O Código Civil anterior, que datava de 1916, regulava a família do início do século passado, constituída unicamente pelo matrimônio. Em sua versão original, trazia uma estreita e discriminatória visão da família, limitando-a ao grupo originário do casamento. Impedia sua dissolução, fazia distinções entre seus membros e trazia qualificações discriminatórias às pessoas unidas sem casamento e aos filhos havidos dessas relações. As referências feitas aos vínculos extramatrimoniais e aos filhos ilegítimos eram punitivas e serviam exclusivamente para excluir direitos, numa vã tentativa de preservação do casamento. $^{5}$

Conclui-se, portanto, que, sob a ótica do Código Civil de 1916, vigorava o conceito da família matrimonializada, patriarcal, hierarquizada e biológica. Nesse sentido, os ensinamentos de Christiano Chaves de Farias:

\footnotetext{
${ }^{4}$ DIAS, Maria Berenice. Manual de Direito das Famílias. $8^{\mathrm{a}}$ ed. Revisada, Atual e Ampl. São Paulo: Editora Revista dos Tribunais, 2011. p. 29-30.

${ }^{5}$ Ibid., p. 29-30.
} 
Sob a égide do Código Civil de 1916, cuja estrutura era exclusivamente matrimonializada (somente admitida a formação da família pelo casamento), dizia-se que o Direito das Famílias era o complexo de normas e princípios que regulam a celebração do casamento, sua validade e os efeitos que dele resultam, as relações pessoais e econômicas da sociedade conjugal, a dissolução desta, as relações entre pais e filhos, o vínculo de parentesco e os institutos complementares da tutela, curatela e da ausência. ${ }^{6}$

\subsection{A relação conjugal pré Constituição de 1988}

Não obstante as inúmeras demandas pleiteadas por diversos movimentos feministas e as diversas conquistas obtidas por parte das mulheres, ainda hoje, verifica-se tratamento desigual no que diz respeito aos gêneros.

Tal realidade ainda se observa nos dias atuais, no contexto de um ordenamento jurídico voltado para isonomia e inclusão. Nesse esteio, há de se imaginar a falta de respaldo vigente antes do advento da Carta Magna de 1988, a qual positivou o princípio da igualdade de gêneros em seu artigo $5^{\circ}$, I.

No cenário jurídico anterior à Constituição Federal de 1988, reflexo de uma sociedade machista, as mulheres recebiam tratamento jurídico bastante diferenciado. Tal situação se refletia no direito de família, que elencava inúmeras desigualdades entre os gêneros. Nesse contexto, a mulher, na relação familiar, era uma figura submissa ao marido, quem detinha o poder familiar. A legislação pretérita relegava à mulher a função de cuidadora dos filhos e do lar, situação que contrasta veementemente com o atual cenário, em que houve a ascensão feminina nas universidades e nos postos de trabalho.

Destacam-se, do código Civil de 1916, alguns dispositivos que personificam a sociedade tradicionalista e patriarcal da época. No que se refere à capacidade para os atos da vida civil, retirou-se da mulher sua plena capacidade, de modo a torna-la relativamente capaz (Inciso II do Art. $6^{\circ}$ do

\footnotetext{
${ }^{6}$ FARIAS, Cristiano Chaves de; ROSENVALD, Nelson. Direitos Reais. Direito Civil: Famílias. $7^{\text {a }}$ ed. Rio de Janeiro: Editora Atlas, 2015. p. 13.
} 
$\mathrm{CC} / 16$ ). Além disso, era necessário consentimento do chefe de família para que a mulher pudesse trabalhar e praticar outros atos da vida civil (Art. 242 do CC/16). Por fim, embora se dedicasse exclusivamente aos seus filhos, não possuía poder pleno de decisão sobre eles, o qual era conferido ao patriarca (Art. 380 do CC/16).

Nesse sentido, eis as lições de Maria Berenice Dias:

A presença da mulher é uma história de ausência. Como bem refere Rodrigo da Cunha Pereira, o lugar dado pelo direito à mulher sempre foi um não lugar. Sua voz nunca foi ouvida e seu pensamento não era convidado a participar. Relegada da cena pública e política, sua força produtiva sempre foi desconsiderada, não sendo reconhecido o valor econômico dos afazeres domésticos. A ela era imposta a submissão, e aos filhos a obediência. ${ }^{7}$

O Código Civil de 1916 elencava como deveres do marido a representação legal da família, a gestão dos bens comuns e particulares do cônjuge, sustento familiar (Art. 233 do CC/16). Constava ainda, no referido diploma legal, caber somente à mulher o direito de pleitear alimentos provisionais, uma verdadeira demonstração da concepção machista vigente (Art. 224 do CC/16). Por fim, lamentavelmente, ao marido era garantido o direito de não mais prover auxílios financeiros à mulher, no caso de abandono dela do lar onde residia o casal (Art. 234 do CC/16).

Atualmente, contudo, observa-se a mudança nesse cenário. Ainda que lentamente, os diplomas legais vêm retratando a emancipação feminina e a conquista de espaço no seio social. A mulher não é mais tida como mera funcionária do lar e responsável pelos cuidados com os filhos, mas sim como pessoa capaz de prover a família, tendo em vista a inserção feminina nas universidades e no mercado de trabalho. Nesse esteio, seguem os comentários de Maria Berenice Dias:

Embora de modo acanhado e vagarosamente, os textos legais acabam retratando a trajetória da mulher. Ainda que lenta, a emancipação jurídica da mulher, a conquista por um lugar ao sol, abalou a organização da família, forçando o declínio da sociedade conjugal patriarcal. (...) Hoje, a mulher, na plenitude de sua

\footnotetext{
${ }^{7}$ DIAS, 2011, p. 97.
} 
condição feminina, é parte fundante da estrutura social e passou a exercer funções relevantes para sua emancipação pessoal e profissional, para a sociedade e para a família. E, sempre que se fala em mulher, impositivo render homenagens ao movimento feminista. Apesar de tão ridicularizado, enfim conseguiu o que todas sempre ansiaram: liberdade e igualdade. ${ }^{8}$

Pode-se concluir que o papel da mulher era baseado na submissão ao homem e às tarefas do lar. Não se verificava uma real igualdade de gêneros positivada, como há no ordenamento jurídico atual o que ensejava tratamento discriminatório em relação à mulher.

Contudo, por meio da Constituição Cidadã, consolidou-se, pelo menos do ponto de vista normativo, a isonomia entre os gêneros. Conquanto haja necessidade de evolução, foram consolidados como pilares atuais das entidades familiares o afeto, a solidariedade e a assistência mútua.

\subsection{A parentalidade antes da Constituição de 1988: o pátrio poder}

Segundo ensina Flávio Tartuce:

Filiação pode ser conceituada como sendo a relação jurídica decorrente do parentesco por consanguinidade ou outra origem, estabelecida particularmente entre os ascendentes e os descendentes de primeiro grau. Em suma, trata-se da relação jurídica existente entre os pais e os filhos. O dispositivo inaugural quanto ao tema, o art. 1556 do CC/02, foi exaustivamente analisado no Capítulo I desta obra, consagrando o princípio da igualdade entre os filhos e repetindo o que constava no art. 227 , parágrafo $6^{\circ}$, da CF. ${ }^{9}$

Conforme exposto anteriormente, a família é o instrumento ideal para desenvolvimento e realização da pessoa humana, sendo certo que no seio familiar são travadas as primeiras relações com a sociedade, com o fito de alavancar o desenvolvimento da personalidade. Dessa forma, a filiação é um dos principais meios aptos a formar entidades familiares.

\footnotetext{
${ }^{8}$ DIAS, 2011, p. 97.

${ }^{9}$ TARTUCE, Flávio. Direito Civil: Direito de Família. 5a ed. Editora Forense, 2017. p. 417.
} 
Haja vista ser a família um agrupamento de cidadãos heterogêneos, é fundamental, para realização pessoal de seus membros, existir o respeito às individualidades, a fim de se estabelecerem oportunidades para construção da identidade do sujeito. Nesse sentido, Christiano Chaves de Farias assim define a filiação:

\begin{abstract}
Assim, sob o ponto de vista técnico-jurídico, a filiação é a relação de parentesco estabelecida entre pessoas que estão no primeiro grau, em linha reta entre uma pessoa e aqueles que a geraram ou que a acolheram e criaram, com base no afeto e na solidariedade, almejando o desenvolvimento da personalidade e a realização pessoal. Remete-se, pois, ao conteúdo do vínculo jurídico entre as pessoas envolvidas (pai/mãe e filho), trazendo a reboque atribuições e deveres variados. ${ }^{10}$
\end{abstract}

A Constituição Cidadã foi responsável por remodelar completamente a abordagem referente à filiação. $\mathrm{O}$ tratamento discriminatório entre os filhos, o tratamento sucessório distinto e a relegação a segundo plano do instituto da adoção eram marcantes no ordenamento jurídico brasileiro.

Destaca-se que, diferentemente do cenário atual, no qual se verifica a igualdade entre os filhos, o ordenamento anterior fazia distinções vexatórias, segundo uma classificação estanque em filhos legítimos, ilegítimos, cujo único critério se baseava na concepção ter se dado ou não na constância do casamento.

Sendo a família calcada no casamento a única merecedora da tutela jurídica e do reconhecimento estatal, ao abordar a filiação, o legislador tratava exclusivamente dos filhos gerados durante o casamento. Denotavase, assim, a preponderância da paternidade jurídica em detrimento da verdade biológica, de forma que só recebia proteção a família legítima, sacralizada por meio do matrimônio.

A fim de proteger a família instituída com fulcro no casamento e garantir a manutenção da paz social da família tida como legítima, o ordenamento anterior marginalizava o filho havido fora do casamento. Dessa maneira, a negativa da existência da prole havida fora do casamento

\footnotetext{
${ }^{10}$ FARIAS; ROSENVALD, 2015, p. 543.
} 
beneficiava tão somente o chefe da família, responsável pela prática do adultério, o qual se eximia do poder familiar e as obrigações dele decorrente.

Por outro lado, o indivíduo gerado na relação extraconjugal se via totalmente desamparado, o qual tinha que arcar com o ônus social e financeiro de não poder contar com a figura paterna em sua vida. Tal situação ilustra a visão patriarcal e conservadora vigente à época, em cuja base estrutural se encontrava o instituto do casamento.

Nesse diapasão, eis os ensinamentos de Maria Berenice Dias:

A necessidade de preservação do núcleo familiar - leia-se -, preservação da família - autorizava que os filhos fossem catalogados de forma absolutamente cruel. Fazendo uso de terminologia plena de discriminação, os filhos se classificavam em legítimos, legitimados e ilegítimos. Os ilegítimos, por sua vez, eram divididos em naturais ou espúrios. Os filhos espúrios se subdividiam em incestuosos e adulterinos. Essa classificação tinha como único critério a circunstância de o filho ter sido gerado dentro ou fora do casamento, isto é, o fato de a prole proceder ou não de genitores casados entre si. Assim, a situação conjugal do pai e da mãe refletia-se na identificação dos filhos: conferia-lhes ou subtraía-lhes não só o direito à intimidade, mas também o direito à sobrevivência. ${ }^{11}$

No que toca aos efeitos sucessórios, a desigualdade entre os filhos legítimos e ilegítimos se torna ainda mais evidente. Dessa forma, caso o reconhecimento do filho ilegítimo se desse após o nascimento de um filho legítimo, o filho que fora primeiramente reconhecido só poderia ter direito à metade do que cabia ao filho legítimo nascido posteriormente.

Por sua vez, a adoção, sofria inúmeras restrições pelo Código Civil de 1916, incumbido de sua regulação. Não obstante a adoção ser considerada, antes de 1988, um meio capaz de ensejar a filiação, deveria ser atendida uma série requisitos por parte das partes envolvidas no processo. Destacam-se a idade mínima do adotante (Art. 368, CC/16), a duração do casamento (parágrafo único do Art. 368, CC/16) e a diferença de idade ser

\footnotetext{
${ }^{11}$ DIAS, 2011, p. 355.
} 
de ao menos 18 anos entre o postulante à adoção e o menor que seria adotada (Art. 369, CC/16).

A Constituição Cidadã elevou as crianças e os adolescentes a sujeitos de direito. Tal configuração, associada à consolidação dos princípios constitucionais da dignidade da pessoa humana, da igualdade, da liberdade, do melhor interesse da criança e do adolescente propiciou a formulação da doutrina da proteção integral. Calcado em tais princípios, o ordenamento pátrio pôs fim a um processo histórico de discriminação, a fim de promover a isonomia entre todos os filhos, independentemente do momento e das circunstâncias de sua concepção.

Nesse sentido, os ensinamentos do Ministro do Superior Tribunal de Justiça, Rodrigo Salomão:

Observa-se que, após a Constituição de 1988, houve uma verdadeira revolução jurisprudencial no que diz respeito aos direitos de família, aplicando-se, a partir de então, o princípio da igualdade entre os filhos, independentemente da origem.

Assim, se antes da Constituição de 1988 a jurisprudência tratava desigualmente os filhos adotivos e os ilegítimos, especialmente no que se refere aos direitos sucessórios, a partir do disposto no art. $227, \S 6^{\circ}$, da CF, embora ainda inexistente legislação infraconstitucional que disciplinasse a matéria, foi reconhecida, pretoriamente, uma série de direitos decorrentes do instituto da adoção, não apenas em termos patrimoniais, mas também no que se refere aos direitos de personalidade, como a possibilidade de promover investigação de paternidade para reconhecimento de filiação biológica, pois o 'estado de filiação é direito personalíssimo, indisponível e imprescritível, podendo ser exercitado contra os pais ou herdeiros, sem qualquer restrição, mesmo em se tratando, como na espécie, de autor adotado por parentes'. ${ }^{12}$

${ }^{12}$ SAlOMÃO, Luis Felipe. Direito Privado: Teoria e Prática. $2^{\mathrm{a}}$ ed. Rev. Atual. Eampl. Rio de Janeiro: Forense, 2014. p. 3. 


\section{CAPÍTULO 2 - A FAMÍLIA NA CONSTITUIÇÃO CIDADÃ}

Marcada pela intensa participação social e pela valorização da pessoa humana e seus atributos, a Carta Magna de 1988 buscou acompanhar a dinâmica das relações sociais, de modo a inserir em seu arcabouço normativo um conjunto de princípios capazes de nortear o instituto da família e a valorização de seus integrantes.

Nessa perspectiva, não só a legislação, mas também a jurisprudência pátria, devem buscar refletir as demandas e a realidade sociais. Um ordenamento jurídico que não esteja em sintonia com sociedade na qual está inserido se mostra obsoleto e pouco representativo.

Embora os temas atinentes à família sejam tratados como matéria constitucional desde 1934, observa-se que, somente com o advento da Constituição Cidadã, houve real preocupação em se proteger a família nas suas mais variadas acepções. Diferentemente do ordenamento jurídico anterior, que só concebia como legítima a família fundada no casamento, atualmente, valorizam-se diversas formas de surgimento de tal vínculo, desde que observada a presença do afeto e da solidariedade.

Nesse diapasão, eis as lições de Guilherme Calmon Nogueira da Gama:

Na ordem jurídica brasileira, desde a Constituição Federal de 1934, a família passou a ser expressamente tratada em nível constitucional, a despeito das críticas feitas por alguns ao legislador constituinte, sob o argumento de que tal assunto não era materialmente constitucional. Não foi postura exclusivamente adotada no direito nacional, conforme noticiam Jean Carbonier e Paolo BiscarettiRuffia. Observa-se, claramente, que a inserção da família nas Constituições coincidiu com o advento do Estado Social, já que este passou a ter maior preocupação com as relações familiares em suas variadas manifestações sociais. Contudo, a proteção especial do Estado, prevista no texto constitucional, apenas tinha como 
destinatária a família matrimonial, porquanto apenas o casamento era reconhecido como instituto formador e legitimador da família brasileira. ${ }^{13}$

\subsection{A constitucionalização do direito civil}

A Constituição Federal de 1988 representa a retomada do processo democrático brasileiro, que nos remonta ao mais duradouro segmento histórico de estabilidade no Brasil. Seu arcabouço normativo simboliza eclética aglutinação de interesses dos mais diversos setores e categorias, os quais estavam marginalizados após longo período ditatorial.

O fenômeno da constitucionalização do direito é recente no Brasil, não obstante se trate de um marco crucial no processo de elaboração e interpretação das normas jurídicas. A partir da constitucionalização, a Carta Magna, além de gozar da histórica supremacia formal, passa a desfrutar de supremacia material, o que é maximizado pela normatividade de seus princípios, com base nos quais deve ser interpretada a legislação infraconstitucional.

A constitucionalização do direito civil é um processo por meio do qual se realiza a interpretação dos institutos do direito civil de acordo com a Constituição Federal. Embora a norma seja de direito privado, sua análise deve se pautar nos princípios elencados na Carta Magna. Como exemplo, pode-se destacar o fornecimento de alimentos nas uniões homoafetivas, o que é um reflexo dos princípios constitucionais da igualdade e da dignidade da pessoa humana.

Como já abordado, no cenário político e social anterior à atual Constituição, preponderava, como base normativa, o Código Civil de 1916, marcado por um viés essencialmente patrimonialista, patriarcal e conservador. Contudo, após o advento da Carta Política de 1988, tal eixou se deslocou.

${ }^{13}$ GAMA, Guilherme Calmon Nogueira da. Princípios constitucionais de direito de família: guarda compartilhada à luz da lei no 11.698/08: família, criança, adolescente e idoso. São Paulo: Atlas, 2008. p. 113-114. 
Nesse esteio, eis as lições do Ministro Luís Roberto Barroso:

Do centro do sistema jurídico brasileiro foi descolocado o velho Código Civil. Veja-se que o direito civil desempenhou no Brasil - como alhures - o papel de um direito geral, que precedeu muitas áreas de especialização, e que conferia certa unidade dogmática ao ordenamento. A própria teoria geral do Direito era estudada dentro do direito civil, e só mais recentemente adquiriu autonomia didática. No caso brasileiro, deve-se registrar, o Código Civil de já vinha perdendo influencia no âmbito do direito privado. É que, ao longo do tempo, à medida que o Código envelhecia, inúmeras leis específicas foram editadas, passando a formar microssistemas autônomos em relação a ele, em temas como alimentos, filiação, divórcio, locação, consumidor, criança e adolescente, sociedades empresariais. A exemplo do que se passou na Itália, também entre nós deu-se a 'descodificação' do direito civil, fenômeno que não foi afetado substancialmente pela promulgação do Código Civil em 2002, com vigência a partir de 2003. ${ }^{14}$

Dentro dessa perspectiva, a Constituição Federal se posiciona no centro do ordenamento jurídico, sendo a matriz de sua força normativa. Além de ser o parâmetro gerador de validade da legislação infraconstitucional, a Carta Política é o paradigma através do qual devem ser interpretadas as normas jurídicas oriundas de outras searas jurídicas.

Desse modo, segundo a doutrina do Ministro Luís Roberto Barroso ${ }^{15}$, a constitucionalização não se refere somente à inclusão, na Carta Magna, de disciplinas jurídicas atinentes a outras esferas do direito, mas, sobretudo, na reinterpretação dessas normas com bases nos preceitos constitucionais.

O fenômeno da constitucionalização do direito civil, no que toca ao direito de família, se materializa em diversos aspectos. Destacam-se a igualdade entre os filhos - com o fim da classificação odiosa entre legítimos e ilegítimos -; a igualdade entre os cônjuges; a pluralidade de vínculos hábeis a ensejar a formação da família, dado que atualmente o casamento não mais figura como único meio capaz de constituir tal entidade.

\footnotetext{
14 BARROSO, Luís Roberto. Curso de Direito Constitucional Contemporâneo: Os conceitos fundamentais e a construção do novo modelo. $4^{\mathrm{a}}$ ed. São Paulo: Ed Saraiva, 2013. p. 389.

${ }^{15}$ Ibid., p. 269-270, 390
} 
Nota-se, nesse contexto, a preponderância do afeto em detrimento de noções meramente patrimoniais, o que é reflexo da consolidação principiológica da dignidade da pessoa humana, elencada na Carta Magna como um dos fundamentos da República. Para ratificar tal entendimento, invoca-se novamente a doutrina do Ministro Luís Roberto Barroso:

\begin{abstract}
Mas há dois desenvolvimentos que merecem destaque, pela dimensão das transformações que acarretam.

O primeiro deles diz respeito ao princípio da dignidade da pessoa humana na nova dogmática jurídica. Ao término da Segunda Guerra Mundial, tem início a reconstrução dos direitos humanos, que se irradiam a partir da dignidade da pessoa humana, referência que passou a constar dos documentos internacionais e das Constituições democráticas, tendo figurado na carta brasileira de 1988 como um dos fundamentos da República (art. $1^{\circ}$, III). A dignidade humana impõe limites e atuações positivas do Estado, no atendimento das necessidades vitais básicas, expressando-se em diferentes dimensões. No tema específico aqui versado, o princípio promove uma despatrimonialização e uma repersonalização do direito civil, com ênfase em valores existenciais e do espírito, bem como no reconhecimento e desenvolvimento dos direitos da personalidade, tanto em sua dimensão física como psíquica. ${ }^{16}$
\end{abstract}

Por meio do fenômeno da constitucionalização do direito de família, houve evoluções históricas fundamentais, as quais serão abordadas mais à frente. A flexibilização do conceito de família desfez o entrelaço até então existe entre entidade familiar o casamento, sendo este meio exclusivo para constituição daquela.

Desse modo, as mais diversas formas de família mereceram tutela jurídica, seja a união estável entre um homem e uma mulher, seja a união entre pessoas do mesmo sexo. De igual modo, as relações monoparentais foram abarcadas dentro do conceito, valorizando o núcleo formado por apenas um dos genitores e seus filhos.

Nesse sentido, destacam-se as lições de Maria Berenice Dias:

Essa é uma característica do chamado Estado Social, que intervém em setores da vida privada como forma de proteger o cidadão, postura impensável em um Estado liberado que prestia, antes e acima de tudo, a liberdade. O direito civil

\footnotetext{
${ }^{16}$ BARROSO, 2013, p. 396-397.
} 
constitucionalizou-se, afastando-se da concepção individualista, tradicional e conservadora-elitista das codificações do século passado. Agora, qualquer norma jurídica de direito das famílias exige a presença de fundamento de validade constitucional. Essa é a nova tábua de valores da Constituição Federal, especialmente no tocante à igualdade de tratamento dos cônjuges. Tanto o marido como a mulher podem livremente praticar todos os atos de disposição e de administração ao desempenho de sua profissão. Foi afastada a concepção antiga de que a mulher era mera colaboradora do marido na administração dos bens, na chefia da sociedade conjugal e no exercício do poder familiar. ${ }^{17}$

\subsection{A parentalidade na CRFB/88: o pátrio poder e o poder familiar}

As leis anteriores à Carta Magna de 1988 regulamentavam o paradigma da família patriarcal, no qual os filhos havidos fora do casamento e as demais espécies de entidades familiares que não fossem fundadas no casamento eram privados da tutela jurisdicional.

Nesse período histórico, a família patriarcal era instituto legislativo basilar, destacando-se, a título de exemplo, a indissolubilidade do casamento e a capacidade relativa da mulher.

No que se refere ao exercício do comando familiar, o artigo 233 do Código Civil de 1916 determinava a exclusividade do marido como único chefe da sociedade conjugal. Conforme previsão do artigo 240, do mesmo diploma legal, a mulher estava limitada à incumbência de colaboração nos no exercício dos encargos da família. In verbis:

Art. 240- A mulher, com o casamento, assume a condição de companheira, consorte e colaboradora do marido nos encargos de família, cumprindo-lhe zelar pela direção material e moral desta.

Art. 233. O marido é o chefe da sociedade conjugal.

Compete-lhe:

I. A representação legal da família.

II. A administração dos bens comuns e dos particulares da mulher, que ao marido competir administrar em virtude do regime matrimonial adaptado, ou do pacto antenupcial.

III. direito de fixar e mudar o domicílio da família

IV. O direito de autorizar a profissão da mulher e a sua residência fora do tecto conjugal.

\footnotetext{
${ }^{17}$ DIAS, 2011, p. 36.
} 
V. Prover à manutenção da família, guardada a disposição do art. $277 .{ }^{18}$

Consoante o entendimento de Maria Helena Diniz ${ }^{19}$, o pátrio poder pode ser compreendido como "conjunto de direitos e obrigações quanto à pessoa e aos bens do filho menor não emancipado, em igualdade de condições, por ambos os pais, para que possam desempenhar os encargos que a norma jurídica lhe impõe, tendo em vista o interesse e a proteção do filho".

Segundo entendimento da doutrina, o pátrio poder era visto como o conjunto de deveres e prerrogativas referentes desenvolvimento do filho menor. Nessa perspectiva, o Código Civil de 1916 conferiu ao marido a titularidade do exercício do pátrio poder. Era incumbência do homem o exercício de tal poder em relação aos filhos menores. Somente na hipótese de ausência ou impedimento do marido, poderia a mulher exercer a chefia da sociedade conjugal.

Tendo em vista os princípios consagrados pela Constituição de 1988, o pátrio poder se tornou anacrônico no ordenamento pátrio, por colidir com diversos valores presentes no Estado Social Democrático, como a igualdade de gêneros, de filiação e o princípio do melhor interesse da criança.

Nesse sentido, atualmente, não cabe mais aos pais exercer um poder sobre seus filhos, mas sim um dever legal de proteção, orientação e auxílio. A vontade dos pais é minorada em função da ascensão do princípio do melhor interesse da criança e do adolescente, os quais figuram como sujeitos de direitos em relação a quem devem ser oferecidas todas as garantias para o pleno desenvolvimento.

Segundo entendimento de Flávio Tartuce ${ }^{20}$, o poder familiar é conceituado como "o poder exercido pelos pais em relação aos filhos, dentro da ideia de família democrática, do regime de colaboração familiar e

\footnotetext{
${ }^{18}$ BRASIL. Lei no 3.071, de $1^{\circ}$ de janeiro de 1916. Código Civil (1916).

${ }^{19}$ DINIZ, Maria Helena. Dicionário Jurídico. v. 3. São Paulo: Ed. Saraiva, 1998. p. 543.

${ }^{20}$ TARTUCE, 2017, p. 507.
} 
de relações baseadas, sobretudo, no afeto. O instituto está regulado nos arts. 1.630 a 1.638 do CC/02".

Os filhos estão sujeitos ao poder familiar enquanto perdurar a menoridade, sendo certo que tal poder deve ser exercido por ambos os cônjuges, o que denota a eliminação da preponderância da figura paterna, que se verificava anteriormente.

O poder familiar encontra-se disciplinado nos artigos 1.634 do Código Civil e no artigo 22 do Estatuto da Criança e do Adolescente, conforme se observa a seguir:

Art. 1.634. Compete a ambos os pais, qualquer que seja a sua situação conjugal, o pleno exercício do poder familiar, que consiste em, quanto aos filhos: (Redação dada pela Lei ${ }^{\circ}$ 13.058, de 2014)

I - dirigir-lhes a criação e a educação; (Redação dada pela Lei no 13.058 , de 2014)

II - exercer a guarda unilateral ou compartilhada nos termos do art. 1.584; (Redação dada pela Lei $n^{\circ} 13.058$, de 2014)

III - conceder-lhes ou negar-lhes consentimento para casarem; (Redação dada pela Lei $n^{\circ} 13.058$, de 2014)

IV - conceder-lhes ou negar-lhes consentimento para viajarem ao exterior; (Redação dada pela Lei $n^{\circ} 13.058$, de 2014)

$\mathrm{V}$ - conceder-lhes ou negar-lhes consentimento para mudarem sua residência permanente para outro Município; (Redação dada pela Lei $n^{\circ} 13.058$, de 2014)

VI - nomear-lhes tutor por testamento ou documento autêntico, se o outro dos pais não lhe sobreviver, ou o sobrevivo não puder exercer o poder familiar; (Redação dada pela Lei $\mathrm{n}^{\circ} 13.058$, de 2014)

VII - representá-los judicial e extrajudicialmente até os 16 (dezesseis) anos, nos atos da vida civil, e assisti-los, após essa idade, nos atos em que forem partes, suprindo-lhes o consentimento; (Redação dada pela Lei $n^{\circ} 13.058$, de 2014)

VIII - reclamá-los de quem ilegalmente os detenha; (Incluído pela Lei nº 13.058 , de 2014)

IX - exigir que lhes prestem obediência, respeito e os serviços próprios de sua idade e condição. (Incluído pela Lei no 13.058 , de 2014). ${ }^{21}$

Art. 22. Aos pais incumbe o dever de sustento, guarda e educação dos filhos menores, cabendo-lhes ainda, no interesse destes, a obrigação de cumprir e fazer cumprir as determinações judiciais.

Parágrafo único. A mãe e o pai, ou os responsáveis, têm direitos iguais e deveres e responsabilidades compartilhados no cuidado e na educação da criança, devendo ser resguardado o direito de transmissão familiar de suas crenças e

\footnotetext{
${ }^{21}$ BRASIL. Art. 1.634. Lei n 10.406 , de 10 de janeiro de 2002. Código Civil.
} 
culturas, assegurados os direitos da criança estabelecidos nesta Lei. (Incluído pela Lei $n^{\circ} 13.257$, de 2016). ${ }^{22}$

Da leitura dos dispositivos acima transcritos, causa estranheza o inciso IX do artigo 1.634 do Código Civil. Embora a obediência e o respeito sejam inerentes à relação do filho com seus genitores, a exigência de "prestação de serviços próprios de sua idade e condição" remete a uma concepção anacrônica, própria do pátrio poder, em que a prole se vê em situação de total subordinação ao chefe da família. No mais, a interpretação extensiva e descuidada do referido diploma legal pode conduzir ao degradante cenário de exploração da mão-de-obra infantil em atividades laborais não condizentes com a faixa em que se encontram.

Fixada tal ressalva, cumpre ressaltar que, com a vigência do ECA, foi elevado ao status de direito personalíssimo o reconhecimento do estado de filiação. A partir do advento do Estatuto, as crianças e os adolescentes, até então marginalizados, foram protegidos pelo princípio da proteção integral, consoante previsão do seu artigo $4^{\circ}$ :

Art. 4. É dever da família, da comunidade, da sociedade em geral e do poder público assegurar, com absoluta prioridade, a efetivação dos direitos referentes à vida, à saúde, à alimentação, à educação, ao esporte, ao lazer, à profissionalização, à cultura, à dignidade, ao respeito, à liberdade e à convivência familiar e comunitária. Parágrafo único. A garantia de prioridade compreende:

a) primazia de receber proteção e socorro em quaisquer circunstâncias;

b) precedência de atendimento nos serviços públicos ou de relevância pública;

c) preferência na formulação e na execução das políticas sociais públicas;

d) destinação privilegiada de recursos públicos nas áreas relacionadas com a proteção à infância e à juventude..$^{23}$

Portanto, tendo em vista a emancipação gradativa da mulher e o reconhecimento de igualdade e dignidade aos filhos (não obstante a origem advir ou não do casamento), entrou em desuso o pátrio poder, uma vez que incompatível com os valores consagrados pela Constituição Federal de

\footnotetext{
${ }^{22}$ BRASIL. [Estatuto da criança e do adolescente (1990)]. Art. 22. Lei n. 8.069, de 13 de julho de 1990.

${ }^{23}$ Ibid., Art. 4.
} 
1988. Sendo assim, a ideia de um poder do chefe de família em relação aos demais membros do grupo sucumbiu, fazendo emergir a concepção de autoridade parental. Contudo, esta deve ser entendida como uma função, uma incumbência dos genitores de garantir proteção, saúde, educação aos seus filhos. Tem-se, por fim, uma função educativa, em detrimento da noção estritamente patrimonial.

\subsection{A dessacralização do casamento e as novas formas de surgimento do vínculo familiar}

A interpretação do conceito de casamento, assim como todos os demais institutos do Direito de Família, é reflexo das dinâmicas relações sociais que se permutam ao longo do tempo. Tendo em vista ser a família uma entidade em constante transformação, o casamento tem de se moldar às mudanças sociais, políticas econômicas.

Segundo a concepção de Clóvis Beviláqua, autor que se filia à concepção contratualista, o casamento é um contrato bilateral e solene, pelo qual um homem e uma mulher se unem indissoluvelmente, legitimando por ele suas relações sexuais; estabelecendo a mais estreita comunhão de vida e de interesses, e comprometendo-se a criar e educar a prole que de ambos nascer.

Não obstante se tratar de um renomado jurista, a noção conceitual de casamento sofreu, ao longo das últimas décadas, profundas transformações. Modernamente, as bases nas quais se escora o referido instituto são o afeto, a solidariedade, o respeito, a busca pela realização pessoal, a comunhão de um projeto de vida em conjunto.

Destacam-se as lições de Rolf Madaleno:

A comunhão plena de vida torna-se condição e validade de todo casamento, atributo indispensável de sua existência e subsistência porque seria inconcebível perpetuar no tempo qualquer relação conjugal que dela se ressentisse. (...) Não faz qualquer sentido manter unido um casal que confesse não estar feliz, porque não mais encontra,ou talvez porque nunca tenha encontrado em seu 
relacionamento este atributo indissolúvel da absoluta e imprescindível integral comunhão de vida. ${ }^{24}$

Nesse sentido, eis o entendimento de Caio Mário da Silva Pereira:

Caio Mário definiu o casamento como a união de duas pessoas de sexo diferente, realizando uma integração fisiopsíquica permanente. É nesta integração que subsiste a essência do casamento, elemento que se sobrepõe às mutações sociais e culturais. Não se pode afirmar que a vida do casal, composta de um homem e uma mulher, é, nos dias atuais, a única forma de vida familiar e comunitária. ${ }^{25}$

Apesar de o conceito de Caio Mário elencar como um dos requisitos do casamento a diversidade de sexo, deve-se salientar que, consoante decisão do Supremo Tribunal Federal, proferida na Ação Direita de Inconstitucionalidade 4.277, é reconhecida, no Brasil a união entre pessoas do mesmo sexo, a chamada união homoafetiva. Nessa perspectiva, destacase acórdão prolatado pelo Superior Tribunal de Justiça:

CASAMENTO. PESSOAS. IGUALDADE. SEXO. In casu, duas mulheres alegavam que mantinham relacionamento estável há três anos e requereram habilitação para o casamento junto a dois cartórios de registro civil, mas o pedido foi negado pelos respectivos titulares. Posteriormente ajuizaram pleito de habilitação para o casamento perante a vara de registros públicos e de ações especiais sob o argumento de que não haveria, no ordenamento jurídico pátrio, óbice para o casamento de pessoas do mesmo sexo. Foi-lhes negado o pedido nas instâncias ordinárias. O Min. Relator aduziu que, nos dias de hoje, diferentemente das constituições pretéritas, a concepção constitucional do casamento deve ser plural, porque plurais são as famílias; ademais, não é o casamento o destinatário final da proteção do Estado, mas apenas o intermediário de um propósito maior, qual seja, a proteção da pessoa humana em sua dignidade. Assim sendo, as famílias formadas por pessoas homoafetivas não são menos dignas de proteção do Estado se comparadas com aquelas apoiadas na tradição e formadas por casais heteroafetivos. O que se deve levar em consideração é como aquele arranjo familiar deve ser levado em conta e, evidentemente, o vínculo que mais segurança jurídica confere às famílias é o casamento civil. Assim, se é o casamento civil a forma pela qual o Estado melhor protege a família e se são múltiplos os arranjos familiares reconhecidos pela CF/1988, não será negada essa via a nenhuma família que por ela optar, independentemente de orientação sexual dos nubentes, uma vez que as famílias constituídas por pares homoafetivos possuem os mesmos núcleos axiológicos daquelas constituídas por casais heteroafetivos, quais sejam, a dignidade das pessoas e o afeto. Por consequência, o mesmo raciocínio utilizado tanto pelo STJ quanto pelo STF para conceder aos pares homoafetivos os direitos decorrentes da união estável deve ser utilizado para lhes proporcionar a via do casamento civil, ademais porque a CF determina a

\footnotetext{
${ }^{24}$ MADALENO, Rolf. Curso de Direito de Família. Rio de Janeiro: Forense, 2008. p. 73-74.

${ }^{25}$ PEREIRA, 2013, p. 71.
} 
facilitação da conversão da união estável em casamento (art. 226, § $3^{\circ}$ ). Logo, ao prosseguir o julgamento, a Turma, por maioria, deu provimento ao recurso para afastar o óbice relativo à igualdade de sexos e determinou o prosseguimento do processo de habilitação do casamento, salvo se, por outro motivo, as recorrentes estiverem impedidas de contrair matrimônio. ${ }^{26}$

A partir do posicionamento das Cortes Superiores, a matéria foi sacramentada com jurisdição para todo o território brasileiro. Desse modo, atualmente, os órgãos e membros do Poder Judiciário não podem ir de encontro à orientação proferida em caráter vinculativo pela Suprema Corte. Sendo assim, a interpretação dos dispositivos legais referentes ao casamento deve ser calcada no novo entendimento estabelecido pelo Supremo Tribunal Federal e pelo Superior Tribunal de Justiça.

Passada a tentativa conceitual, deve-se salientar que uma das principais mudanças elencadas pela Constituição Federal de 1988 foi a viabilidade da formação de uma entidade familiar sem a necessidade do matrimônio. Até então, como abordado, o casamento era o único instituto apto a ensejar a constituição de uma família. Aponta-se o entendimento de Maria Berenice Dias:

\begin{abstract}
Quando da edição do Código Civil de 1916, era de tal ordem a sacralização da família, que havia um único modo de constituir-se: pelo casamento. A família tinha viés patriarcal, e as regras legais refletiam essa realidade. Somente era reconhecida a família ungida pelos sagrados laços do matrimônio. Não havia outra modalidade de convívio aceitável. O casamento era indissolúvel. A resistência do Estado em admitir relacionamento outros era de tal, que a única possibilidade de romper com o casamento era o desquite, que não dissolvia o vínculo matrimonial, e, com isso, impedia novo casamento. ${ }^{27}$
\end{abstract}

Todavia, a nova realidade social acarretou a evolução de tal entendimento. A Constituição Cidadã alargou o conceito de família, de modo que foram reconhecidas e tuteladas outras formas de família. A entidade familiar, assim, passa a ser compreendida com base no afeto, na solidariedade existente entre seus membros, em detrimento da concepção

\footnotetext{
${ }^{26}$ STJ, REsp 1.183.378/RS, Rel. Min. Luiz Felipe Salomão, Brasília, j. 25.10.2011.

${ }^{27}$ DIAS, Maria Berenice. Manual de direito das famílias. $8^{\mathrm{a}}$. ed. Rev., Atual. Eampl. São Paulo: Editora Revista dos Tribunais, 2011. p. 146-147.
} 
tradicional e formalista até então vigente. Destacam-se a união estável, a família monoparental, a parentalidade socioafetiva.

Nesse diapasão, enfatiza-se o artigo 226 da Carta Magna:

Art. 226. A família, base da sociedade, tem especial proteção do Estado.

$\S 1^{\circ} \mathrm{O}$ casamento é civil e gratuita a celebração.

$\S 2^{\circ} \mathrm{O}$ casamento religioso tem efeito civil, nos termos da lei.

$\S 3^{\circ}$ Para efeito da proteção do Estado, é reconhecida a união estável entre o homem e a mulher como entidade familiar, devendo a lei facilitar sua conversão em casamento.

$\S 4^{\circ}$ Entende-se, também, como entidade familiar a comunidade formada por qualquer dos pais e seus descendentes.

$\S 5^{\circ}$ Os direitos e deveres referentes à sociedade conjugal são exercidos igualmente pelo homem e pela mulher.

$\S 6^{\circ} \mathrm{O}$ casamento civil pode ser dissolvido pelo divórcio.

$\S 7^{\circ}$ Fundado nos princípios da dignidade da pessoa humana e da paternidade responsável, o planejamento familiar é livre decisão do casal, competindo ao Estado propiciar recursos educacionais e científicos para o exercício desse direito, vedada qualquer forma coercitiva por parte de instituições oficiais ou privadas.

$\S 8^{\circ} \mathrm{O}$ Estado assegurará a assistência à família na pessoa de cada um dos que a integram, criando mecanismos para coibir a violência no âmbito de suas relações. ${ }^{28}$

Como se extrai do parágrafo $3^{\circ}$ do artigo 226, elevou-se a união entre o homem e mulher ao status de família, ainda que não haja entre eles o vínculo formal do casamento. Consagrou-se, assim, a isonomia entre os dois modelos familiares, haja vista formalidade não poder se sobrepor ao propósito de vida em comum, à comunhão de projetos, à solidariedade e ao afeto.

Nessa esteira, a Constituição Federal representa um ponto de inflexão importante, porquanto conferiu proteções e garantias a núcleos familiares até então desprestigiados e juridicamente desamparados. Eis as lições de Christiano Chaves de Farias:

\footnotetext{
28 BRASIL. Constituição (1988). Constituição da República Federativa do Brasil. Brasília, DF,
} Senado, 1998. 
Com a Lex Matter de 1988, a situação se modificou, ganhando novos ares. A família foi pluralizada, assumindo novas feições. O casamento perdeu a exclusividade, mas não a proteção. Continua merecedor da especial proteção do Estado (CF, art. 226), como uma das formas possíveis para a constituição de uma entidade familiar, através de uma união formal, solene, entre pessoas humanas. Apenas não mais possui a característica da exclusividade, convivendo com outros mecanismos de constituição de família, como a união estável, a família monoparental, a família homoafetiva... Dispõe, textualmente, o caput do art. 226 da Carta Maior que a família, base da sociedade, tem especial proteção do Estado, revelando, de forma evidente, que todo e qualquer núcleo familiar, tenha sido constituído do modo que for, merecerá a proteção estatal, não podendo sofrer discriminações. O casamento, em meio a essa multiplicidade de núcleos afetivos, continua protegido, apenas perdendo o exclusivismo. ${ }^{29}$

Segundo a concepção moderna, portanto, o casamento não mais funcionada como uma instituição jurídica através da qual se consolidava a família. O constituinte positivou nova carga axiológica, com a inserção dos princípios da solidariedade, da igualdade, da liberdade e, sobretudo, da dignidade da pessoa humana.

O casamento deve servir como meio através da qual os cônjuges alcancem a realização pessoal e a felicidade, tendo em vista a valorização da pessoa humana. A tutela solene do casamento se pautava na busca pela manutenção da família, mesmo que isso implicasse malefícios aos seus integrantes.

Atualmente, todavia, haja vista serem o matrimônio e a família institutos próprios ao desenvolvimento da pessoa humana, busca-se tutelar a dignidade de seus membros, tanto dos cônjuges como de seus descendentes. O casamento, portanto, deve se pautar nos vínculos afetivos, servindo de instrumento para a realização pessoal dos integrantes do grupo familiar, reconhecida a valorização da pessoa humana.

\footnotetext{
${ }^{29}$ FARIAS; ROSENVALD, 2015, p. 141.
} 


\section{CAPÍTULO 3 - PRINCÍPIOS NORTEADORES DO DIREITO DE FAMÍLIA}

Conforme abordado anteriormente, a Constituição Federal de 1988 goza não só de supremacia formal, mas também material, de modo que todos os institutos jurídicos devem ter sua interpretação calcada nos ditames constitucionais. Os princípios possuem força normativa, sendo os balizadores da valorização da dignidade da pessoa humana.

Nota-se, assim, que os princípios constitucionais são a base de todo o ordenamento jurídico pátrio, são as vigas de sustentação da estrutura legal vigente no país. Ao contrário do que se passava anteriormente, os princípios não são meras diretrizes orientadoras das normas infraconstitucionais, uma vez que possuem força normativa e são imprescindíveis para a consecução do ideal de justiça.

Nesse sentido, os ensinamentos de Maria Berenice Dias:

A partir do momento em que ocorreu a constitucionalização do direito civil e a dignidade da pessoa humana foi consagrada como fundamento do Estado Democrático de Direito ( $\mathrm{CF}, 1^{\circ}$, III), o positivismo tornou-se insuficiente. As regras jurídicas mostraram-se limitadas, acanhadas para atender ao comando constitucional. O princípio da interpretação conforme a Constituição é uma das mais importantes inovações, ao propagar que a lei deve ser interpretada, sempre, a partir da lei maior. Assim, os princípios constitucionais passaram a informar todo o sistema legal de modo a viabilizar o alcance da dignidade humana em todas as relações jurídicas. ${ }^{30}$

Os princípios possuem uma textura aberta, são proposições genéricas, com base nas quais devem se pautar não só os legisladores, mas também os intérpretes e os julgadores. Por sua vez, as regras têm textura fechada, representam descrições de conduta de essência objetiva. Quando se tem um conflito de regras incidentes sobre o mesmo fato, a resolução se dá pela escolha de uma em detrimento da outra, segundo critérios de especialidade, cronologia ou hierarquia.

\footnotetext{
${ }^{30}$ DIAS, 2011, p. 57-58.
} 
Por sua vez, os princípios não comportam tal solução, uma vez que não há hierarquia entre as normas constitucionais. Desse modo, cabe ao intérprete a árdua missão de ponderá-los, tentando maximizar tanto quanto possível cada uma das normas colidentes. Nas palavras de Maria Berenice Dias:

\begin{abstract}
A partir do transbordamento dos princípios constitucionais para todos os ramos do direito, passou-se a enfrentar o problema do conflito de princípios ou colisão de direitos fundamentais. Nessas hipóteses - que não são raras, principalmente em sede de direito das famílias -, é mister invocar o princípio da proporcionalidade, que prepondera sobre o princípio da estreita legalidade. Não cabe a simples anulação de um princípio para total observância do outro. É preciso observar, tanto quanto possível, as garantias momentaneamente antagônicas, sem privar qualquer delas de sua substância elementar. Quando dois princípios incidem sobre determinado fato, o conflito é solucionado levando-se em consideração o peso relativo de cada um. Há ponderação entre os princípios, e não opção por um deles em detrimento do outro. Havendo conflito entre princípios de igual importância hierárquica, o fiel da balança, a medida da ponderação, o objetivo a ser alcançado já está determinado, a priori, em favor do princípio, hoje absoluto, da dignidade da pessoa humana. ${ }^{31}$
\end{abstract}

Nessa perspectiva, os princípios podem ser considerados o alicerce sobre o qual emerge o ordenamento jurídico. Trata-se de preposições genéricas que disciplinam todo o sistema jurídico. Com o advento da Carta Magna de 1988, ganha muita importância o estudo dos princípios, tendo em vista servirem de parâmetro interpretativo, sobretudo no direito das famílias. A fim de melhor compreender a preponderância da principiologia, traz-se uma analogia apresentada por Marcos Jorge Catalan:

Imagine-se na base da Cordilheira dos Andes, prestes a escalar o Monte Aconcágua, mais alto pico da América do Sul. Superada a preparação física, é essencial, para o sucesso do projeto, no mínimo, o material do alpinismo. Assim, principalmente nas escarpas e nas rotas negativas, a cada metro ou dois, será cravado na rocha um pino de sustentação, sem o qual a subida tornar-se-á deveras arriscada, pois, a qualquer momento, o alpinista pode desprender-se da rocha numa viagem fatal ao solo, empurrado pela força da gravidade. Princípios, assim, são fontes imediatas do direito na delicada operação de exegese do caso concreto que venha a ser submetido o hermeneuta, que necessariamente deverá perpassar, em cada situação fática que se lhe apresente, por todo o sistema para que assim,

\footnotetext{
${ }^{31}$ DIAS, 2011, p. 59.
} 
por meio de uma análise axiológica sistemática, possa iniciar seu trabalho interpretativo com a certeza de atingir resultados seguros. ${ }^{32}$

\subsection{O princípio da igualdade}

O princípio da igualdade, na seara dos direitos das famílias, possui duas vertentes de inestimável valor. Consoante demonstrado nesta obra, antes do avento da Constituição Federal de 1988, imperava no Brasil um ordenamento jurídico essencialmente patriarcal, conservador, voltado para a regulação das relações patrimoniais.

Por meio da Constituição Cidadã, a qual contou com a participação efetiva de diversos setores da sociedade civil, todos com pleitos legítimos, consolidou-se o entendimento segundo o qual a família não é um fim em si mesma, mas sim um meio através do qual seus membros buscam alcançar a realização pessoal.

Nesse sentido, consolidou-se a igualdade entre os filhos como princípio constitucional, em detrimento da ideia abarcada pela legislação anterior, a qual trazia distinções preconceituosas, em razão de a concepção da criança ter se dado ou não durante a vigência de uma relação matrimonial.

Por sua vez, a discrepante desigualdade entre os gêneros foi abolida, após séculos de tratamento preconceituoso conferido às mulheres. Nesse contexto, cabe ressaltar que a Constituição Federal de 1988 optou por consagrar o princípio da igualdade material, em função do qual devem ser observadas as peculiaridades físicas, biológicas, sociais de cada um, bem como suas necessidades individuais.

A Constituição Federal definiu no caput do artigo $5^{\circ}$ que todos são iguais perante a lei. Não bastasse tal enunciado, ratificou-se a igualdade de gênero no inciso I do artigo $5^{\circ}$, ao estabelecer que homens e mulheres são

32 CATALAN, Marcos Jorge. Descumprimento Contratual - Modalidades, Consequências e Hipóteses de Exclusão do Dever de Indenizar. 1 ${ }^{\text {a }}$. Curitiba: Juruá, 2005. p. 37. 
iguais em direitos e obrigações. De igual modo, no parágrafo $5^{\circ}$ do artigo 226 , é reforçada a isonomia de direitos e obrigações no que diz respeito à sociedade conjugal.

A insistência do constituinte se mostra totalmente adequada, tendo em vista o tratamento dispensado às mulheres nas legislações anteriores. A concepção da mulher como mera cuidadora do lar, responsável pela educação dos filhos e subordinada ao marido foi superada. Atualmente, nota-se cada vez mais a inserção feminina nas universidades e no mercado de trabalho. Desse modo, crucial a ênfase do legislador em promover a igualdade material.

Eis a lição de Christiano Chaves de Farias:

A regra da igualdade não consiste senão em quinhoar desigualmente aos desiguais, na medida em que se desigualam. Nesta desigualdade social, proporcionada à desigualdade natural, é que se acha a verdadeira lei da igualdade. O mais são desvarios da inveja, do orgulho, ou da loucura. Tratar com desigualdade a iguais, ou a desiguais com igualdade, seria desigualdade flagrante, e não igualdade real. Os apetites humanos conceberam inverter a norma universal da criação, pretendendo, não dar a cada um, na razão do que vale, mas atribuir o mesmo a todos como se todos se equivalessem.

Singrando esses mares, infere-se, com certeza e convicção, que o verdadeiro sentido da igualdade substancial é tratar desigualmente quem está em posição desigual e tratar igualmente quem está na mesma posição jurídica. Ou seja, o princípio da isonomia pode resultar na necessidade de tratamento igual ou desigual, a depender das circunstâncias fáticas das pessoas envolvidas na relação jurídica. Estando na mesma posição, o tratamento tem de ser igual; havendo posição fática subjacente de desigualdade, o tratamento necessariamente será desigual para respeitar a igualdade. ${ }^{33}$

Em consonância com os ditames constitucionais, o Código Civil de 2002 abarcou em seu texto normativo inúmeros dispositivos que consagram a igualdade entre homens e mulheres, responsáveis por compartilhar o poder familiar, conduzir a educação dos filhos, gerir os bens tanto da sociedade conjugal quanto dos descendentes.

\footnotetext{
${ }^{33}$ FARIAS; ROSENVALD, 2015, p. 89-90.
} 
Art. 1.511. O casamento estabelece comunhão plena de vida, com base na igualdade de direitos e deveres dos cônjuges.

Art. 1.567. A direção da sociedade conjugal será exercida, em colaboração, pelo marido e pela mulher, sempre no interesse do casal e dos filhos.

Parágrafo único. Havendo divergência, qualquer dos cônjuges poderá recorrer ao juiz, que decidirá tendo em consideração aqueles interesses.

Art. 1.565. Pelo casamento, homem e mulher assumem mutuamente a condição de consortes, companheiros e responsáveis pelos encargos da família.

$\S 1$ Q Qualquer dos nubentes, querendo, poderá acrescer ao seu o sobrenome do outro.

$\S 2$ o O planejamento familiar é de livre decisão do casal, competindo ao Estado propiciar recursos educacionais e financeiros para o exercício desse direito, vedado qualquer tipo de coerção por parte de instituições privadas ou públicas.

Art. 1.631. Durante o casamento e a união estável, compete o poder familiar aos pais; na falta ou impedimento de um deles, o outro o exercerá com exclusividade.

Parágrafo único. Divergindo os pais quanto ao exercício do poder familiar, é assegurado a qualquer deles recorrer ao juiz para solução do desacordo.

Art. 1.690. Compete aos pais, e na falta de um deles ao outro, com exclusividade, representar os filhos menores de dezesseis anos, bem como assisti-los até completarem a maioridade ou serem emancipados.

Parágrafo único. Os pais devem decidir em comum as questões relativas aos filhos e a seus bens; havendo divergência, poderá qualquer deles recorrer ao juiz para a solução necessária. ${ }^{34}$

O princípio da igualdade também se manifesta na prestação de alimentos, dada a possibilidade de qualquer dos cônjuges requerer o fornecimento ao outro, dadas as condições e peculiaridades fáticas. Não obstante tradicionalmente fosse o homem o provedor das verbas de natureza alimentícia, atualmente, é consolidado na jurisprudência o entendimento de que, no caso de a mulher possuir condições materiais para seu próprio

\footnotetext{
${ }^{34}$ BRASIL. Art. 1.634. Lei n ${ }^{\circ} 10.406$, de 10 de janeiro de 2002. Código Civil.
} 
sustento, estando em idade produtiva apta a atuar no mercado de trabalho, não faz jus às verbas alimentares.

Nesse sentido, eis o entendimento do Superior Tribunal de Justiça:

\begin{abstract}
Alimentos transitórios. A estipulação de alimentos transitórios (por tempo certo) é possível quando o alimentando ainda possui idade, condição e formação profissional compatíveis com sua provável inserção no mercado de trabalho. Assim, a necessidade de alimentos perdura apenas até que se atinja a aguardada autonomia financeira, pois, nesse momento, não mais necessitará de tutela do alimentante, então, liberado da obrigação (que se extinguirá automaticamente). ${ }^{35}$
\end{abstract}

Por fim, ressalta-se o princípio da igualdade entre os filhos. Conforme visto, a Carta Magna de 1988, ao estabelecer o princípio da proteção integral da criança e do adolescente, desconstitui a ideia do pátrio poder, até então vigente, cuja base ideológica consistia na noção hierarquizada da família, calcada na primazia paterna.

Nessa perspectiva, em que a família funciona como instrumento para o desenvolvimento dos seus membros, sobretudo dos menores, há a intensa proteção da criança e do adolescente, de modo que o artigo 226 consagra, em seu parágrafo $5^{\circ}$, que "os filhos, havidos ou não da relação do casamento, terão os mesmos direitos e qualificações, proibidas quaisquer designações discriminatórias relativas à filiação ${ }^{36}$.

Dessa forma, conclui-se que a natureza do vínculo que junge os genitores - seja casamento, seja união estável, seja união homoafetiva, seja um encontro fortuito - não pode determinar tratamentos discriminatórios no que se refere aos filhos havidos da relação.

De igual modo, a origem da filiação - seja biológica, seja socioafetiva - também não enseja distinções de direitos entre a prole. Tal noção é um reflexo direto do princípio da afetividade, tido como pilar do direito das famílias constitucionalizado. Eis o entendimento de Caio Mário da Silva Pereira:

\footnotetext{
${ }^{35}$ STJ, REsp. 1.025.769/MG, Rel. Min. Nancy Andrighi, j. 24.08.2010.

${ }^{36}$ BRASIL. Constituição (1988). Constituição da República Federativa do Brasil. Brasília, DF, Senado, 1998.
} 
Consolida-se a família socioafetiva em nossa Doutrina e Jurisprudência, uma vez declarada a convivência familiar e comunitária como Direito Fundamental, a não discriminação de filhos, a corresponsabilidade dos pais quanto ao exercício do poder familiar e o núcleo monoparental reconhecido como entidade familiar. (...)

Situações peculiares devem ser assumidas no mundo jurídico como relações de afeto com força própria para uma definição jurídica: o filho de criação, quando comprovado o estado de filho afetivo (posse de estado de filho), a adoção judicial, o reconhecimento voluntário ou judicial da paternidade ou maternidade e a conhecida adoção à brasileira. ${ }^{37}$

\subsection{O princípio da dignidade da pessoa humana}

A Constituição Federal de 1988 elevou a dignidade da pessoa humana a fundamento republicano, conforme se observa da leitura de seu artigo $1^{\circ}$, inciso III. Tal postulado deve ser entendido como princípio máximo, a partir do qual se irradiam os demais.

O princípio da dignidade da pessoa humana abarca a cidadania em sua genuína acepção, assim considerada na consciência de pertencimento à sociedade estatal como titular de direitos e garantias fundamentais. Assegura-se, de tal modo, a inclusão das diversas camadas sociais, baseada em uma relação de respeito na qual são totalmente vedados quaisquer tipos de distinções odiosas e vexatórias.

Nessa esteira, as alterações na realidade fática vêm recebendo, paulatinamente, tutela por parte do ordenamento jurídico pátrio. Nesse cenário de constituição de novos paradigmas de famílias se faz imprescindível o papel desempenhado pelo princípio da dignidade da pessoa humana, com o fito de reconhecimento dos novos vínculos capazes de formar a entidade familiar, com destaque para o afeto.

A necessidade de valorização dos direitos humanos acarretou a consagração da dignidade humana como princípio fundamental da República, como núcleo a partir do qual devem ser interpretados os institutos jurídicos. Na seara do direito das famílias, em torno de tal

\footnotetext{
${ }^{37}$ PEREIRA, 2013, p. 46.
} 
princípio se fundaram os demais, entre os quais destacam-se a liberdade, o pluralismo, a solidariedade, a igualdade.

Eis as preciosas lições de Maria Berenice Dias:

Na medida em que a ordem constitucional elevou a dignidade da pessoa humana a fundamento da ordem jurídica, houve uma opção expressa pela pessoa, ligando todos os institutos à realização de sua personalidade. Tal fenômeno provocou a despatrimonialização e a personalização dos institutos jurídicos, de modo a colocar a pessoa humana no centro protetor do direito. O princípio da dignidade humana não representa apenas um limite à atuação do Estado, mas constitui também um norte para a sua atuação positiva. O Estado não tem apenas o dever de abster-se de praticar atos que atentem contra a dignidade humana, mas também deve promover essa dignidade através de condutas ativas, garantindo o mínimo existencial para cada ser humano em seu território. ${ }^{38}$

Tendo em vista estar o direito de família intimamente ligado à defesa dos direitos humanos, a projeção do princípio da dignidade humana denota a igual dignidade a todas as entidades familiares, a todos os filhos, a todas relações afetivas. Dessa forma, consagrou-se o tratamento isonômico entre os filhos, independentemente da natureza do vínculo que une os genitores, bem como retirou-se do casamento a exclusividade de meio capaz de ensejar a constituição de família.

Apresentada a análise conceitual e axiológica, propõe-se a identificação de alguns desdobramentos oriundos do princípio da proteção da dignidade da pessoa humana.

Inicialmente, destaca-se o fortificado entendimento do Superior Tribunal de Justiça, o qual considera o imóvel ocupado por pessoa solteira como bem de família, merecedor da proteção garantida pela impenhorabilidade:

Processual. Execução. Impenhorabilidade, Imóvel. Residência. Devedor solteiro e solidário - Lei 8.009/1990. A interpretação teleológica do art. $1^{\circ}$, da Lei 8.009/1990, revela que a norma não se limita ao resguardo da família. Seu escopo definitivo é a proteção de um direito fundamental da pessoa humana: o direito à moradia. Se assim ocorre, não faz sentido proteger quem vive em grupo e abandonar o indivíduo que sofre o mais doloroso dos sentimentos: a solidão. É

\footnotetext{
${ }^{38}$ DIAS, 2011, p. 63.
} 
impenhorável, por efeito do preceito contido no art. $1^{\circ}$ da Lei 8.009/1990, o imóvel em que reside, sozinho, o devedor celibatário. ${ }^{39}$

RECURSO ESPECIAL. DIREITO CIVIL. EXECUÇÃO. EMBARGOS DE TERCEIROS.PENHORA INCIDENTE SOBRE IMÓVEL NO QUAL RESIDEM FILHAS DO EXECUTADO.BEM DE FAMÍLIA. CONCEITO AMPLO DE ENTIDADE FAMILIAR.RESTABELECIMENTO DA SENTENÇA. 1. "A interpretação teleológica do Art. $1^{\circ}$, da Lei $8.009 / 90$, revela que a norma não se limita ao resguardo da família. Seu escopo definitivo é a proteção de um direito fundamental da pessoa humana: o direito à moradia" (EREsp 182.223/SP, Corte Especial, Rel. Min. Humberto Gomes de Barros, DJ 6/2/2002). 2. A impenhorabilidade do bem de família visa resguardar não somente o casal, mas o sentido amplo de entidade familiar. Assim, no caso de separação dos membros da família, como na hipótese em comento, a entidade familiar, para efeitos de impenhorabilidade de bem, não se extingue, ao revés, surge em duplicidade: uma composta pelos cônjuges e outra composta pelas filhas de um dos cônjuges. Precedentes. 3. A finalidade da Lei no 8.009 /90 não é proteger o devedor contra suas dívidas, tornando seus bens impenhoráveis, mas, sim, reitera-se, a proteção da entidade familiar no seu conceito mais amplo. 4. Recurso especial provido para restabelecer a sentença. ${ }^{40}$

Conforme se pode observar, a ementa da decisão se contextualiza dentro de um cenário no qual houve não só o alargamento do conceito de família, mas também a preponderância da valorização de seus membros. O cediço entendimento do Tribunal da Cidadania ensejou a edição da Súmula 364, in verbis: "O conceito de impenhorabilidade de bem de família abrange também o imóvel pertencente a pessoas solteiras, separadas e viúvas".

Como segundo exemplo, aponta-se a recente jurisprudência dos tribunais nacionais, no sentido de proceder à condenação dos pais ao pagamento de indenização a seus filhos, em razão de abandono afetivo. Tais decisões tem como ratio o princípio da dignidade humana, uma vez que cabe aos genitores zelar pela formação, instrução e desenvolvimento de seus descendentes.

Nesse sentido, é direito fundamental da criança e do adolescente a convivência com os pais. Na perspectiva constitucional de família, tem-se

\footnotetext{
${ }^{39}$ STJ, EREsp 182.223/SP, Corte Especial, Rel. Min. Sálvio de Figueiredo Teixeira, São Paulo, j. 06.02.2002.

${ }^{40}$ STJ, REsp 1.126.173, $3^{\mathrm{a}}$ Turma, Rel. Min. Ricardo Villas Bôas Cueva, Minas Gerais, j. 09.04.2013.
} 
como núcleo a afetividade. Desse modo, a família não pode ser compreendia como uma relação marcada por hierarquia e subordinação, mas sim por solidariedade, respeito e assistência. Os pais possuem deveres impostos pela Carta Magna, entre os quais são citados o direito à saúde, educação, relação de parentesco, respeito, solidariedade e afeto. O princípio da afetividade é um reflexo do macroprincípio da dignidade da pessoa humana.

Em um primeiro momento, o entendimento do Superior Tribunal de Justiça postulava que o pai não estaria obrigado a conviver com o filho, razão pela qual não caberia a procedência do pleito indenizatório. O afeto do pai em relação ao filho era tido como uma faculdade, que não poderia ser imposta, de forma que não haveria que se falar em ilicitude.

Modernamente, contudo, contata-se a evolução na jurisprudência do Tribunal da Cidadania. Com fulcro na decisão proferida pela Ministra Nancy Andrighi, no Resp 1.159.242/SP, sedimentou-se a formulação de nova jurisprudência, que compreende o dever de cuidado como uma obrigação constitucionalmente imposta aos pais, com base no art. 227 da Carta Magna.

CIVIL E PROCESSUAL CIVIL. FAMÍLIA. ABANDONO AFETIVO. COMPENSAÇÃO POR DANO MORAL. POSSIBILIDADE. 1. Inexistem restrições legais à aplicação das regras concernentes à responsabilidade civil e o consequente dever de indenizar/compensar no Direito de Família. 2. O cuidado como valor jurídico objetivo está incorporado no ordenamento jurídico brasileiro não com essa expressão, mas com locuções e termos que manifestam suas diversas desinências, como se observa do art. 227 da CF/88. 3. Comprovar que a imposição legal de cuidar da prole foi descumprida implica em se reconhecer a ocorrência de ilicitude civil, sob a forma de omissão. Isso porque o non facere, que atinge um bem juridicamente tutelado, leia-se, o necessário dever de criação, educação e companhia - de cuidado - importa em vulneração da imposição legal, exsurgindo, daí, a possibilidade de se pleitear compensação por danos morais por abandono psicológico. 4. Apesar das inúmeras hipóteses que minimizam a possibilidade de pleno cuidado de um dos genitores em relação à sua prole, existe um núcleo mínimo de cuidados parentais que, para além do mero cumprimento da lei, garantam aos filhos, ao menos quanto à afetividade, condições para uma adequada formação psicológica e inserção social. 5. A caracterização do abandono afetivo, a existência de excludentes ou, ainda, fatores atenuantes - por demandarem revolvimento de matéria fática - não podem ser objeto de reavaliação na estreita via do recurso especial. 6. A alteração do valor fixado a título de compensação por danos morais é possível, em recurso especial, nas 
hipóteses em que a quantia estipulada pelo Tribunal de origem revela-se irrisória ou exagerada. 7. Recurso especial parcialmente provido. ${ }^{41}$

Após destacar a viabilidade da condenação por danos morais nas relações familiares, a Ministra vislumbrou a configuração do ilícito tendo em vista a inescusável incumbência dos pais em fornecer respaldo psicológico aos filhos. Dessa forma, o ato ilícito se faz presente em decorrência do abandono afetivo do pai, que inadimpliu com seu dever jurídico de cuidado. Não obstante a impossibilidade de compelir um genitor a nutrir sentimentos por seus filhos, a ilustre jurista cunhou uma frase que se disseminou no meio jurídico: "Amar é faculdade. Cuidar é dever".

Por fim, como terceiro exemplo de desdobramento do princípio da dignidade da pessoa humana, salienta-se a busca pela felicidade, assunto já tratado quando da abordagem das diversas formas hábeis a constituir a família e a filiação. Nesse sentindo, a decisão do Supremo Tribunal Federal no julgamento do Recurso Extraordinário 898.060/SC, reconheceu, em 2016, a igualdade entre a paternidade biológica e a socioafetiva, bem como a possibilidade de multiparentalidade, cujo vínculo é simultâneo.

Tendo em vista a constitucionalização do direito das famílias, devese reinterpretar a análise dos vínculos parentais, tendo como parâmetro o princípio da dignidade da pessoa humana e da busca pela consecução dos próprios projetos. A aplicação desse princípio pressupõe que escolha dos meios para se alcançar a felicidade deve se sobrepor à eventual engessada estrutura legal definidora de modelos estáticos.

O princípio positivado no art. $1^{\circ}$, inciso III é responsável por elevar o indivíduo ao centro do ordenamento jurídico, de modo que não cabe ao Estado intervir na esfera de autonomia privada do cidadão, a qual se molda para o alcance de seus objetivos pessoais. Sendo assim, o direito à busca pela felicidade é vetor de proteção dos sujeitos de direito, de forma que são

\footnotetext{
${ }^{41}$ STJ, REsp 1.159.242/SP, $3^{\mathrm{a}}$ Turma, Rel. Min. Nancy Andrighi, São Paulo, j. 24.04.2012, Dje 10.05.2012.
} 
repelidas as tentativas estatais de cercear as relações familiares meramente em função do encaixe com paradigmas legalmente impostos.

\begin{abstract}
Decisão: O Tribunal, por maioria e nos termos do voto do Relator, fixou tese nos seguintes termos: "A paternidade socioafetiva, declarada ou não em registro público, não impede o reconhecimento do vínculo de filiação concomitante baseado na origem biológica, com os efeitos jurídicos próprios", vencidos, em parte, os Ministros Dias Toffoli e Marco Aurélio. Ausente, justificadamente, o Ministro Roberto Barroso, participando do encontro de juízes de Supremas Cortes, denominado Global Constitutionalism Seminar, na Universidade de Yale, nos Estados Unidos. Presidiu o julgamento a Ministra Cármen Lúcia. Plenário, 22.09.2016. ${ }^{42}$
\end{abstract}

\title{
3.3 Princípio da afetividade
}

Malgrado não esteja positivado na Carta Magna como um direito fundamental, o afeto assume, atualmente, protagonismo no que se refere ao direito das famílias. Pode-se identificar o afeto como o principal desdobramento do fundamento republicano da dignidade da pessoa humana.

A afetividade, que corresponde à interação entre as pessoas, tem sido cada vez mais invocada não só pela doutrina, mas também por inúmeras decisões judiciais. Com fulcro em tal princípio, solidificou-se a concepção de parentalidade socioafetiva e a união entre pessoas do mesmo sexo.

Desse modo, embora não haja previsão explícita no texto constitucional, verifica-se que a afetividade é um princípio basilar do direito das famílias, o núcleo em torno do qual devem ser interpretadas as normas, assim como se dá com o postulado da dignidade da pessoa humana.

Paulo Lôbo ${ }^{43}$, contudo, identifica na Constituição Federal quatro fundamentos essenciais do princípio da afetividade: (a) a igualdade de todos os filhos independentemente da origem $\left(227, \S 6^{\circ}, \mathrm{CF}\right)$; (b) a adoção, como escolha afetiva com igualdade de direitos $\left(227, \S 5^{\circ}\right.$ e $\left.6^{\circ}, \mathrm{CF}\right)$; (c) a comunidade formada por qualquer dos pais e seus descendentes, incluindo os adotivos, com a mesma dignidade da família $\left(226, \S 4^{\circ}, \mathrm{CF}\right)$; (d) o direito

\footnotetext{
${ }^{42}$ STF, RE 898.060/SC, Rel. Min. Luiz Fux, Distrito Federal, j. 22.09.2016.

${ }^{43}$ LÔBO, Paulo. Código Civil - Famílias. 6a ed. São Paulo: Saraiva, 2015. p. 47.
} 
à convivência familiar como prioridade absoluta da criança, do adolescente e do jovem $(227, \mathrm{CF})$.

O afeto está inserido no contexto da noção eudemonista da família, que ganha força em detrimento de seu caráter meramente instrumental. Segundo a concepção constitucionalizada, a família tem como traços essenciais o amor, o afeto, a intenção de comungar projetos de vida, além da solidariedade recíproca configurada entre seus membros. Com a derrocada da ideia hierarquizada da família, emergiu uma noção democratizada, em que as relações são calcadas no respeito e na assistência mútua.

Eis as lições de Maria Berenice Dias:

Surgiu um novo nome para essa nova tendência de identificar a família pelo seu envolvimento afetivo: a família eudemonista, que busca a felicidade individual vivendo um processo de emancipação de seus membros. O eudemonismo é a doutrina que enfatiza o sentido de busca pelo sujeito de sua felicidade. A absorção do princípio eudemonista pelo ordenamento altera o sentido da proteção jurídica da família, deslocando-o da instituição para o sujeito, como se infere da primeira parte do $\$ 8$ do art. 226 da CF: O Estado assegurará a assistência à família na pessoa de cada um dos componentes que a integram. A possibilidade de buscar formas de realização pessoal e gratificação profissional é a maneira que as pessoas encontram de viver, convertendo-se em seres socialmente úteis, pois ninguém mais deseja e ninguém mais pode ficar confinado à mesa familiar. ${ }^{44}$

A afetividade, como princípio constitucional implícito, tem preponderante incidência no direito de família, de modo que deve não só orientar a interpretação da legislação infraconstitucional, mas também embasar as decisões judiciais. Nesse sentido, ressalta-se a posição defendida pela Ministra Nancy Andrighi, no julgamento do Recurso Especial 1.026.981/RJ, em que sinaliza para o valor jurídico do afeto:

A quebra de paradigmas do Direito de Família tem como traço forte a valorização do afeto e das relações surgidas da sua livre manifestação, colocando à margem do sistema a antiga postura meramente patrimonialista ou ainda aquela voltada apenas ao intuito de procriação da entidade familiar. Hoje, muito mais visibilidade alcançam as relações afetivas, sejam entre pessoas de mesmo sexo, sejam entre o homem e a mulher, pela comunhão de vida e de interesses, pela

\footnotetext{
${ }^{44}$ DIAS, 2011, p. 55.
} 
reciprocidade zelosa entre os seus integrantes. Deve o juiz, nessa evolução de mentalidade, permanecer atento às manifestações de intolerância ou de repulsa que possam porventura se revelar em face das minorias, cabendo-lhe exercitar raciocínios de ponderação e apaziguamento de possíveis espíritos em conflito. A defesa dos direitos em sua plenitude deve assentar em ideais de fraternidade e solidariedade, não podendo o Poder Judiciário esquivar-se de ver e de dizer o novo, assim como já o fez, em tempos idos, quando emprestou normatividade aos relacionamentos entre pessoas não casadas, fazendo surgir, por consequência, o instituto da união estável. A temática ora em julgamento igualmente assenta sua premissa em vínculos lastreados em comprometimento amoroso. ${ }^{45}$

A afetividade apresenta, como uma de suas principais implicações, o surgimento de uma nova forma de parentesco civil, a chamada parentalidade socioafetiva, calcada na posse de estado de filho. Nessa esteira, o atual entendimento jurisprudencial é no sentido de conceber a paternidade não só como aquela proveniente da gravidez fruto de uma coabitação sexual. Certo é que a paternidade nasce de uma decisão autônoma e espontânea, como ocorre na adoção e no acolhimento de um menor que passa a ser tratado como se filho fosse.

A família não mais se limita a uma concepção biológica e econômica, de modo que a identidade genética, por si só, não deve preponderar sobre vínculos afetivos baseados em escolhas livres e em desejo de convivência.

Eis as lições de Flávio Tartuce:

Impõe-se a distinção entre origem biológica e paternidade/maternidade. Em outros termos, a filiação não é um determinismo biológico, ainda que seja da natureza humana o impulso à procriação. Na maioria dos casos, a filiação derivase da relação biológica; todavia, ela emerge da construção cultural e afetiva permanente, que se faz na convivência e na responsabilidade. No estágio em que nos encontramos, há de distinguir o direito de personalidade ao conhecimento da origem genética, com esta dimensão, e o direito à filiação e à paternidade/maternidade, nem sempre genético. $\mathrm{O}$ afeto não é fruto da biologia. Os laços de afeto e de solidariedade derivam da convivência e não do sangue. A história do direito à filiação confunde-se com o destino do patrimônio familiar, visceralmente ligado à consanguinidade legítima. Por isso, é a história da lenta emancipação dos filhos, da redução progressiva das desigualdades e da redução

45 STJ, EDcl no REsp 1.026.981, $3^{\mathrm{a}}$ Turma, Rel. Min. Nancy Andrighi, Distrito Federal, j. 04.08.2010. 
do quantum despótico, na medida da redução da patrimonialização dessas relações. ${ }^{46}$

Nesse sentido, em uma situação hipotética na qual o marido assume como seu o filho de sua esposa, está, nesse momento, configurado o liame afetivo. Posteriormente, após cristalizada a relação socioafetiva entre ambos, não haverá que se cogitar da quebra desse vínculo.

Nesse sentido, destaca-se o enunciado 103, aprovado na I Jornada de Direito Civil:

O Código Civil reconhece, no art. 1.593, outras espécies de parentesco civil além daquele decorrente da adoção, acolhendo, assim, a noção de que há também parentesco civil no vínculo parental proveniente quer das técnicas de reprodução assistida heteróloga relativamente ao pai (ou mãe) que não contribui com seu material fecundante, quer da paternidade socioafetiva, fundada na posse do estado de filho. ${ }^{47}$

Por todo o exposto, conclui-se que o atual perfil da família está destinado à realização dos projetos pessoais e à consecução dos anseios afetivos individuais. Desse modo, a inserção do afeto como valor jurídico e princípio norteador do direito das famílias, tornou incompatível a concepção instrumental e matrimonializada da família, alicerçada exclusivamente no casamento.

\subsection{Princípio do melhor interesse da criança e do adolescente}

Como desdobramento da valorização da dignidade humana e o deslocamento do sujeito de direito para o centro do ordenamento jurídico, o princípio do melhor interesse da criança e do adolescente foi positivado no artigo 227 da Carta Magna. In verbis:

Art. 227. É dever da família, da sociedade e do Estado assegurar à criança, ao adolescente e ao jovem, com absoluta prioridade, o direito à vida, à saúde, à alimentação, à educação, ao lazer, à profissionalização, à cultura, à dignidade, ao

\footnotetext{
46 TARTUCE, 2017, p. 28.

${ }^{47}$ I JORNADA DE DIREITO CIVIL. Enunciado 103. Brasília, 2003.
} 
respeito, à liberdade e à convivência familiar e comunitária, além de colocá-los a salvo de toda forma de negligência, discriminação, exploração, violência, crueldade e opressão. ${ }^{48}$

A Constituição Cidadã confere aos menores todos os direitos inerentes à pessoa humana, tendo em vista a sua singular situação de indivíduo em desenvolvimento. Observa-se, desse modo, a preocupação do constituinte em fomentar gerações instruídas e respaldadas tanto do ponto de vista técnico educacional, como também psicológico. Dessa forma, atribuiu-se não só à família, mas a toda sociedade, o dever de assegurar condições necessárias ao desenvolvimento da criança e do adolescente.

O direito à proteção integral está previsto não só na Carta Magna, mas também no Estatuto da Criança e Adolescente, responsável por esmiuçar regramentos de natureza processual e material, tanto na esfera cível como na penal. Ressaltam-se dispositivos inseridos no ECA:

Art. $3^{\circ}$ A criança e o adolescente gozam de todos os direitos fundamentais inerentes à pessoa humana, sem prejuízo da proteção integral de que trata esta Lei, assegurando-se-lhes, por lei ou por outros meios, todas as oportunidades e facilidades, a fim de lhes facultar o desenvolvimento físico, mental, moral, espiritual e social, em condições de liberdade e de dignidade.

Parágrafo único. Os direitos enunciados nesta Lei aplicam-se a todas as crianças e adolescentes, sem discriminação de nascimento, situação familiar, idade, sexo, raça, etnia ou cor, religião ou crença, deficiência, condição pessoal de desenvolvimento e aprendizagem, condição econômica, ambiente social, região e local de moradia ou outra condição que diferencie as pessoas, as famílias ou a comunidade em que vivem. (incluído pela Lei n 13.257, de 2016)

Art. $4^{\circ}$ É dever da família, da comunidade, da sociedade em geral e do poder público assegurar, com absoluta prioridade, a efetivação dos direitos referentes à vida, à saúde, à alimentação, à educação, ao esporte, ao lazer, à profissionalização, à cultura, à dignidade, ao respeito, à liberdade e à convivência familiar e comunitária. ${ }^{49}$

O tratamento especial atribuído pela Constituição Federal e pelo Estatuto da Criança e do Adolescente decorre da presunção de que, até

${ }^{48}$ BRASIL. Constituição (1988). Constituição da República Federativa do Brasil. Brasília, DF, Senado, 1998.

${ }^{49}$ BRASIL. [Estatuto da criança e do adolescente (1990)]. Lei n. 8.069, de 13 de julho de 1990. 
atingirem a maioridade, os jovens estão em estágio de amadurecimento, desenvolvimento das capacidades cognitivas e certa vulnerabilidade, tendo em vista a pouca experiência.

O princípio do melhor interesse da criança e do adolescente está atrelado à superação do pátrio poder e a consolidação do poder familiar. Segundo a visão constitucionalizada da família, os pais - sobretudo o cônjuge varão - não mais exercem um poder sobre os filhos baseado na autoridade e subordinação. Pelo contrário, possuem dever jurídico de cuidado, constitucionalmente estabelecido, no que diz respeito à prestação de assistência educacional, econômica e psicológica.

O referido princípio possui como um de seus principais desdobramentos a igualdade de filiação na seara das relações familiares, tema já abordado neste trabalho. No mais, pode-se destacar o direito do menor à convivência familiar. Conquanto se busque a sua manutenção na família biológica, é notório que, em muitas ocasiões, os genitores não são os sujeitos mais aptos a atender a incumbência legal que lhes é atribuída, de modo a se mostrar preferível a escolha por uma família substituta. Nesse sentido, eis a posição de Maria Berenice Dias:

\footnotetext{
Em face da garantia à convivência familiar, há toda uma tendência de buscar o fortalecimento dos vínculos familiares e a manutenção de crianças no seio da família natural. Porém, às vezes, melhor atende aos interesses do infante a destituição do poder familiar e a sua entrega à adoção. O que deve prevalecer é o direito à dignidade e ao desenvolvimento integral, e, infelizmente, tais valores nem sempre são preservados pela família. Daí a necessidade de intervenção do Estado, afastando crianças e adolescentes do contato com os genitores, colocando-os a salvo junto a famílias substitutas. O direito à convivência familiar não está ligado à origem biológica da filiação. Não é um dado, é uma relação construída no afeto, não derivando dos laços de sangue. ${ }^{50}$
}

Com fito de ratificar tal posicionamento, traz-se à tona julgado do Superior Tribunal de Justiça, em que se forma o entendimento mediante o qual não cabe anulação do processo de adoção celebrado em consonância com o princípio do melhor interesse da criança:

\footnotetext{
${ }^{50}$ DIAS, 2011, p. 68-69.
} 
ESTATUTO DA CRIANÇA E DO ADOLESCENTE - ECA. ADOÇÃO. INTIMAÇ̃̃O DO MINISTÉRIO PÚBLICO PARA AUDIÊNCIA. ART. 166 DA LEI 8.069/90. FIM SOCIAL DA LEI. INTERESSE DO MENOR PRESERVADO. DIREITO AO CONVÍVIO FAMILIAR. AUSÊNCIA DE PREJUÍZO. NULIDADE INEXISTENTE. Não se declara nulidade por falta de audiência do Ministério Público se - a teor do acórdão recorrido - o interesse do menor foi preservado e o fim social do ECA foi atingido. O Art. 166 da Lei $8.069 / 90$ deve ser interpretado à luz do Art. $6^{\circ}$ da mesma lei. ${ }^{51}$

${ }^{51}$ STJ, REsp 847.597/SC, 3a Turma, Rel. Min. Humberto Gomes de Barros, j. 06.03.2008. 


\section{CAPÍTULO 4 - NOVAS FORMAS DE FAMÍLIA}

Ao se pensar em família, é comum vir à tona o estereótipo historicamente consagrado - o marido e a esposa, jungidos pelo instituto do matrimônio, e sua prole, decorrente de laços biológicos. Contudo, como dito anteriormente, o Direito deve se moldar à realidade social em que está inserido, refletir as novas tendências e novas demandas presentes na sociedade.

A Constituição Cidadã desarticulou o modelo engessado pelo qual somente a família oriunda do matrimônio recebia tutela e proteção jurídicas. Superou-se a visão patrimonialista e patriarcal, fruto da emancipação da mulher e sua inserção definitiva nas universidades e no mercado de trabalho. Desse modo, restam totalmente anacrônicas expressões retrógradas tais como família marginal, informal, extrapatrimonial.

Os princípios estudados no capítulo anterior são responsáveis pela democratização da família, pela igualdade referente à filiação dos filhos, pela derrocada do pátrio poder e pela emergência do poder familiar, cujo exercício é compartilhado por ambos os cônjuges, o que denota a isonomia entre os gêneros, consagrada no artigo $5^{\circ}$ da Lei Maior.

Nesse sentido, as relações familiares são, atualmente, calcadas na igualdade, solidariedade, respeito, assistência mútua, pluralismo e, sobretudo, proteção da dignidade da pessoa humana. Destaca-se, assim, que o alargamento conceitual do instituto da família reflete as transformações políticas, sociais e econômicas observadas na coletividade.

Dentro dessa perspectiva, o pluralismo das relações familiares, como desdobramento do princípio da proteção da pessoa humana, abarcou a proteção constitucional de inúmeros novos paradigmas familiares. Deve-se verificar que, não obstante o artigo 226 da Constituição Federal enumere alguns modelos de família, não se trata de um rol taxativo. 
Tendo em vista o deslocamento da pessoa humana para o eixo central do ornamento jurídico, com enfoque na concretização de realizações pessoais e projetos de vida em comum, o constituinte não teve intenção de estabelecer o casamento, a união estável entre pessoas do mesmo sexo e a família monoparental como únicos modelos constitucionalmente aceitos.

Haja vista a complexidade e as peculiaridades das relações interpessoais, serão apresentados paradigmas familiares já apreciados pelos Tribunais, com entendimento pacificado.

\subsection{A mutação constitucional}

Antes de tratar das novas formas de família, convém analisar o fenômeno da mutação constitucional. Como se sabe, a Carta Magna alberga matérias que não devem estar sujeitas à influência de maiorias eventuais. Embora sejam revestidas de rigidez, as normas constitucionais não devem ter a marca da imutabilidade, uma vez que as transformações verificadas na sociedade ensejam a reconfiguração de regras e princípios.

Nesse esteio, é fundamental que a Constituição se encontre em condições de se moldar a eventuais mudanças ocorridas na sociedade. Desde que respeitados seus princípios norteadores, é viável a alteração do texto constitucional, a fim de que se adeque às vicissitudes sociais.

Dessa forma, a Carta Política estabelece mecanismos para sua alteração. Pela via formal, altera-se o enunciado do dispositivo legal, desde que atendidos os requisitos previstos no parágrafo $2^{\circ}$ do artigo 60 - quórum de dois terços e votação em dois turnos, em cada Casa do Congresso Nacional.

Por sua vez, pela via informal, se tem a mutação constitucional. Tendo por consideração a textura aberta de muitos dos dispositivos presentes na Constituição Federal, é possível efetuar a alteração de sentido das normas constitucionais, ainda que não se opere alteração no texto. 
Nesse sentido, eis as lições do Ministro Luís Roberto Barroso:

À vista dos elementos expostos até aqui, é possível dizer que a mutação constitucional consiste em uma alteração do significado de determinada norma da Constituição, sem observância do mecanismo constitucionalmente previsto para as emendas e, além disso, sem que tenha havido qualquer modificação de seu texto. Esse novo sentido ou alcance do mandamento constitucional pode decorrer de uma mudança na realidade fática ou de uma nova percepção do Direito, uma releitura do que deve ser considerado ético ou justo. Para que seja legítima, a mutação precisa ter lastro democrático, isto é, deve corresponder a uma demanda social efetiva por parte da coletividade, estando respaldada, portanto, pela soberania popular. ${ }^{52}$

Um desdobramento crucial do fenômeno da mutação constitucional pode ser observado no julgamento Ação Direta de Inconstitucionalidade 4.27753. A decisão atribui alteração na interpretação do art. 1.723 do Código Civil, tendo em vista o método de interpretação sistemático, que leva em consideração os princípios e normas constitucionais.

Com base nos princípios da liberdade, do pluralismo e da dignidade humana, há a vedação ao preconceito, de modo que não se pode considerar alguém mais ou menos digno de realizar seus projetos pessoais em razão de sua orientação sexual. O conceito de família foi ampliado, tendo por alicerce a afetividade que une seus membros, em detrimento de um elo meramente formal.

A mutação constitucional encontra limites no respeito ao núcleo central da Constituição. Nas palavras de Luís Roberto Barroso:

A mutação constitucional há de estancar diante de dois limites: a) as possibilidades semânticas do relato da norma, vale dizer, os sentidos possíveis do texto que está sendo interpretado ou afetado; e b) a preservação dos princípios fundamentais que dão identidade àquela específica Constituição. Se o sentido novo que se quer dar não couber no texto, será necessária a convocação do poder constituinte reformador. ${ }^{54}$

À guisa de conclusão, constata-se que a referida decisão proferida na ADI 4.277, a qual confere às pessoas do mesmo sexo o direito de terem sua

\footnotetext{
${ }^{52}$ BARROSO, 2013, p. 148-149.

${ }^{53}$ STF, ADI 4.277, Rel. Min. Ayres Britto, Distrito Federal, j. 05.05.2011.

${ }^{54}$ BARROSO, op. cit., p. 150.
} 
união juridicamente respaldada, vai ao encontro da pricipiologia constitucional e do Estado Democrático de Direito. Concretiza-se, desse modo, o princípio da liberdade, ao permitir que cada indivíduo seja o responsável por traçar as suas diretrizes, sem ingerência estatal nesse processo de tomada de decisão.

\subsection{As famílias homoafetivas}

Historicamente, em função do conservadorismo religioso, a homossexualidade sempre foi vista sob uma ótica marginalizada e preconceituosa. Além de não receber proteção estatal alguma, a união entre pessoas do mesmo gênero ainda precisava conviver com o repúdio social e o tratamento discriminatório.

Atualmente, embora ainda se verifique estar o preconceito enraizado na estrutura social, consolida-se a massificação de movimentos populares com escopo de atender às legítimas demandas pleiteadas pelas pelos homossexuais.

Nas palavras de Maria Berenice Dias:

O fato é que a homossexualidade acompanha a história do homem. Sabe-se de sua existência desde os primórdios dos tempos gregos. Não é crime nem pecado; não é uma doença nem um vício. Também não é um mal contagioso, nada justificando a dificuldade que as pessoas têm de conviver com homossexuais. É simplesmente uma outra forma de viver. A origem não se conhece. Aliás, nem interessa, pois, quando se buscam causas, parece que se está atrás de um remédio, de um tratamento encontrar cura para algum mal. ${ }^{55}$

Conforme exposto neste trabalho, a Constituição Cidadã foi responsável por consagrar a dispensabilidade do casamento para formação de uma entidade familiar. Positivou-se, no artigo 226 da Lei Maior, "a união estável entre homem e mulher" como merecedora de tutela jurídica e proteção estatal.

${ }^{55}$ DIAS, 2011, p. 196. 
Nesse sentido, em um primeiro momento, pairavam dúvidas a respeito da interpretação do referido dispositivo legal, uma vez que, segundo uma interpretação literal, não seria possível a constituição de união estável por pessoas do mesmo sexo.

Contudo, consoante abordado na sessão referente à mutação constitucional (4.1), o Direito deve se adequar à realidade social em que está inserido, haja vista a Constituição Federal não ter a marca da imutabilidade. É possível, assim, redimensionar a interpretação dada a um dispositivo, ainda que não haja alteração formal de seu texto. Para tanto, devem ser respeitados dois parâmetros: as possibilidades semânticas da norma e os princípios fundamentais da Carta Magna.

$\mathrm{Na}$ visão daqueles que eram contrários ao reconhecimento de uniões entre pessoas do mesmo sexo como entidade familiar, deveria ser seguida uma interpretação literal do parágrafo $3^{\circ}$ do artigo 226 da Constituição Federal. Sendo assim, ao se estabelecer que "para efeito da proteção do Estado, é reconhecida a união estável entre o homem e a mulher como entidade familiar", sustentava-se a ideia de que o constituinte estaria vedando qualquer outra forma de união.

Todavia, como analisado no capítulo III, a Constituição Cidadã possui uma base principiológica que irradia a interpretação não só de seus próprios dispositivos, mas também da legislação infraconstitucional. A Lei Maior alocou a proteção dos indivíduos como força motriz de toda sua base normativa. Sendo assim, identifica-se como balizador do sistema jurídico o princípio da dignidade da pessoa humana.

Como desdobramento de tal princípio, resta assegurada a liberdade do ser humano em elaborar seus próprios projetos de vida e buscar sua realização pessoal. Embora a Igreja tenha reconhecido o casamento entre sexos opostos como a via sacra para constituição de uma família, há de se destacar que nem sempre a felicidade é alcançada por via da relação heterossexual. 
Eis os ensinamentos de Christiano Chaves de Faria:

Sem dúvida, não é a diversidade de sexos que garantirá a caracterização de um modelo familiar, pois a afetividade poderá estar presente mesmo nas relações homoafetivas. Outrossim, não se pode olvidar que mesmo os casais homossexuais poderão, eventualmente, experimentar a paternidade, através de reprodução assistida e da ação, conforme vem reconhecendo a jurisprudência mais recente. ${ }^{56}$

Nesse diapasão, imperiosa se faz a análise da Ação Direita de Inconstitucionalidade 4722, movida em face do artigo 1.723 do Código Civil de 2002, o qual preceitua que:

É reconhecida como entidade familiar a união estável entre o homem e a mulher, configurada na convivência pública, contínua e duradoura e estabelecida com o objetivo de constituição de família. ${ }^{57}$

A ação de controle pela via abstrata tinha por fito o reconhecimento da união estável entre pessoas do mesmo sexo. A Procuradora Geral da República, que figurava como parte autora, formulava sua base argumentativa com base nos princípios da dignidade da pessoa humana, da liberdade e da igualdade.

Sustentava-se, na exordial, que embora os homossexuais preenchessem os requisitos referentes à união estável - relação duradoura, pública e contínua, comunhão de vida, projetos afins -, a eles não eram assegurados os direitos que respaldavam a união entre pessoas de sexos distintos.

Defendia a requerente que não reconhecer a união estável entre pessoas do mesmo sexo seria uma flagrante violação ao princípio da isonomia, definido como cláusula pétrea. Diante das possibilidades semânticas oferecidas pelos dispositivos questionados, motivo não haveria para não concessão de tutela jurídica à união formada por homossexuais, tendo em vista que afronta alguma se observa aos princípios fundamentais da Constituição Federal. Pelo contrário, privilegia-se a dignidade humana,

${ }^{56}$ FARIAS; ROSENVALD, 2015, p. 451-452.

${ }^{57}$ ADI 4.722, movida em face do artigo 1.723 do Código Civil de 2002. 
ao possibilitar ao sujeito de direito pautar suas próprias escolhas sem a ingerência estatal.

O Supremo Tribunal Federal, responsável pelo julgamento do caso, estava premido, de um lado, pela literalidade defendida pelo setor mais conservador da sociedade, e, de outro, pelas legítimas pretensões de camadas excluídas.

A ADI 4722 foi julgada em conjunto com a ADPF 132, cuja histórica decisão reconheceu como entidade familiar a união estável firmada entre pessoas do mesmo sexo. O Supremo Tribunal Federal optou pela interpretação sistemática, ao analisar o caso em comento com os princípios norteadores do direito de família. Eis a brilhante decisão:

Ementa: 1. ARGUIÇÃO DE DESCUMPRIMENTO DE PRECEITO FUNDAMENTAL (ADPF). PERDA PARCIAL DE OBJETO. RECEBIMENTO, NA PARTE REMANESCENTE, COMO AÇÃO DIRETA DE INCONSTITUCIONALIDADE. UNIÃO HOMOAFETIVA E SEU RECONHECIMENTO COMO INSTITUTO JURÍDICO. CONVERGÊNCIA DE OBJETOS ENTRE AÇÕES DE NATUREZA ABSTRATA. JULGAMENTO CONJUNTO. Encampação dos fundamentos da ADPF n ${ }^{\circ}$ 132-RJ pela ADI ${ }^{\circ}$ 4.277-DF, com a finalidade de conferir "interpretação conforme à Constituição" ao art. 1.723 do Código Civil. Atendimento das condições da ação.

2. PROIBIÇÃO DE DISCRIMINAÇÃO DAS PESSOAS EM RAZÃO DO SEXO, SEJA NO PLANO DA DICOTOMIA HOMEM/MULHER (GÊNERO), SEJA NO PLANO DA ORIENTAÇÃO SEXUAL DE CADA QUAL DELES. A PROIBIÇÃO DO PRECONCEITO COMO CAPÍTULO DO CONSTITUCIONALISMO FRATERNAL. HOMENAGEM AO PLURALISMO COMO VALOR SÓCIO-POLÍTICO-CULTURAL. LIBERDADE PARA DISPOR DA PRÓPRIA SEXUALIDADE, INSERIDA NA CATEGORIA DOS DIREITOS FUNDAMENTAIS DO INDIVÍDUO, EXPRESSÃO QUE É DA AUTONOMIA DE VONTADE. DIREITO À INTIMIDADE E À VIDA PRIVADA. CLÁUSULA PÉTREA. O sexo das pessoas, salvo disposição constitucional expressa ou implícita em sentido contrário, não se presta como fator de desigualação jurídica. Proibição de preconceito, à luz do inciso IV do art. $3^{\circ}$ da Constituição Federal, por colidir frontalmente com o objetivo constitucional de "promover o bem de todos". Silêncio normativo da Carta Magna a respeito do concreto uso do sexo dos indivíduos como saque da kelseniana "norma geral negativa", segundo a qual "o que não estiver juridicamente proibido, ou obrigado, está juridicamente permitido". Reconhecimento do direito à preferência sexual como direta emanação do princípio da "dignidade da pessoa humana": direito a auto-estima no mais elevado ponto da consciência do indivíduo. Direito à busca da felicidade. Salto normativo da proibição do preconceito para a proclamação do direito à liberdade sexual. $\mathrm{O}$ concreto uso da sexualidade faz parte da autonomia da vontade das pessoas naturais. Empírico uso da sexualidade nos planos da 
intimidade e da privacidade constitucionalmente tuteladas. Autonomia da vontade. Cláusula pétrea.

3. TRATAMENTO CONSTITUCIONAL DA INSTITUIÇÃO DA FAMÍLIA. RECONHECIMENTO DE QUE A CONSTITUIÇÃO FEDERAL NÃO EMPRESTA AO SUBSTANTIVO "FAMÍLIA" NENHUM SIGNIFICADO ORTODOXO OU DA PRÓPRIA TÉCNICA JURÍDICA. A FAMÍLIA COMO CATEGORIA SÓCIO-CULTURAL E PRINCÍPIO ESPIRITUAL. DIREITO SUBJETIVO DE CONSTITUIR FAMÍLIA. INTERPRETAÇÃO NÃOREDUCIONISTA. O caput do art. 226 confere à família, base da sociedade, especial proteção do Estado. Ênfase constitucional à instituição da família. Família em seu coloquial ou proverbial significado de núcleo doméstico, pouco importando se formal ou informalmente constituída, ou se integrada por casais heteroafetivos ou por pares homoafetivos. A Constituição de 1988, ao utilizar-se da expressão "família", não limita sua formação a casais heteroafetivos nem a formalidade cartorária, celebração civil ou liturgia religiosa. Família como instituição privada que, voluntariamente constituída entre pessoas adultas, mantém com o Estado e a sociedade civil uma necessária relação tricotômica. Núcleo familiar que é o principal lócus institucional de concreção dos direitos fundamentais que a própria Constituição designa por "intimidade e vida privada" (inciso $\mathrm{X}$ do art. $5^{\circ}$ ). Isonomia entre casais heteroafetivos e pares homoafetivos que somente ganha plenitude de sentido se desembocar no igual direito subjetivo à formação de uma autonomizada família. Família como figura central ou continente, de que tudo o mais é conteúdo. Imperiosidade da interpretação nãoreducionista do conceito de família como instituição que também se forma por vias distintas do casamento civil. Avanço da Constituição Federal de 1988 no plano dos costumes. Caminhada na direção do pluralismo como categoria sóciopolítico-cultural. Competência do Supremo Tribunal Federal para manter, interpretativamente, o Texto Magno na posse do seu fundamental atributo da coerência, o que passa pela eliminação de preconceito quanto à orientação sexual das pessoas.

4. UNIÃO ESTÁVEL. NORMAÇÃO CONSTITUCIONAL REFERIDA A HOMEM E MULHER, MAS APENAS PARA ESPECIAL PROTEÇÃO DESTA ÚLTIMA. FOCADO PROPÓSITO CONSTITUCIONAL DE ESTABELECER RELAÇÕES JURÍDICAS HORIZONTAIS OU SEM HIERARQUIA ENTRE AS DUAS TIPOLOGIAS DO GÊNERO HUMANO. IDENTIDADE CONSTITUCIONAL DOS CONCEITOS DE "ENTIDADE FAMILIAR" E "FAMÍLIA". A referência constitucional à dualidade básica homem/mulher, no $\S 3^{\circ}$ do seu art. 226 , deve-se ao centrado intuito de não se perder a menor oportunidade para favorecer relações jurídicas horizontais ou sem hierarquia no âmbito das sociedades domésticas. Reforço normativo a um mais eficiente combate à renitência patriarcal dos costumes brasileiros. Impossibilidade de uso da letra da Constituição para ressuscitar o art. 175 da Carta de 1967/1969. Não há como fazer rolar a cabeça do art. 226 no patíbulo do seu parágrafo terceiro. Dispositivo que, ao utilizar da terminologia "entidade familiar", não pretendeu diferenciá-la da "família". Inexistência de hierarquia ou diferença de qualidade jurídica entre as duas formas de constituição de um novo e autonomizado núcleo doméstico. Emprego do fraseado "entidade familiar" como sinônimo perfeito de família. A Constituição não interdita a formação de família por pessoas do mesmo sexo. Consagração do juízo de que não se proíbe nada a ninguém senão em face de um direito ou de proteção de um legítimo interesse de outrem, ou de toda a sociedade, o que não se dá na hipótese sub judice. Inexistência do direito 
dos indivíduos heteroafetivos à sua não-equiparação jurídica com os indivíduos homoafetivos. Aplicabilidade do $\$ 2^{\circ}$ do art. $5^{\circ}$ da Constituição Federal, a evidenciar que outros direitos e garantias, não expressamente listados na Constituição, emergem "do regime e dos princípios por ela adotados", verbis: "Os direitos e garantias expressos nesta Constituição não excluem outros decorrentes do regime e dos princípios por ela adotados, ou dos tratados internacionais em que a República Federativa do Brasil seja parte”.

5. DIVERGÊNCIAS LATERAIS QUANTO À FUNDAMENTAÇÃO DO ACÓRDÃO. Anotação de que os Ministros Ricardo Lewandowski, Gilmar Mendes e Cezar Peluso convergiram no particular entendimento da impossibilidade de ortodoxo enquadramento da união homoafetiva nas espécies de família constitucionalmente estabelecidas. Sem embargo, reconheceram a união entre parceiros do mesmo sexo como uma nova forma de entidade familiar. Matéria aberta à conformação legislativa, sem prejuízo do reconhecimento da imediata auto-aplicabilidade da Constituição.

6. INTERPRETAÇÃO DO ART. 1.723 DO CÓDIGO CIVIL EM CONFORMIDADE COM A CONSTITUIÇÃO FEDERAL (TÉCNICA DA "INTERPRETAÇÃO CONFORME"). RECONHECIMENTO DA UNIÃO HOMOAFETIVA COMO FAMÍLIA. PROCEDÊNCIA DAS AÇÕES. Ante a possibilidade de interpretação em sentido preconceituoso ou discriminatório do art. 1.723 do Código Civil, não resolúvel à luz dele próprio, faz-se necessária a utilização da técnica de "interpretação conforme à Constituição". Isso para excluir do dispositivo em causa qualquer significado que impeça o reconhecimento da união contínua, pública e duradoura entre pessoas do mesmo sexo como família. Reconhecimento que é de ser feito segundo as mesmas regras e com as mesmas consequências da união estável heteroafetiva. ${ }^{58}$

Através da análise do acórdão, constata-se o abandono de uma corrente apegada à frieza da lei e a filiação a um entendimento que encontra respaldo nos princípios da dignidade da pessoa humana, da igualdade e da liberdade, com a consagração definitiva do pluralismo como marca das entidades familiares.

Felizmente, as conquistas não pararam no reconhecimento do vínculo afetivo entre duas pessoas do mesmo sexo como união estável. Atualmente, superada a literalidade do artigo 1.514 do Código Civil, já foi admitida a possibilidade de casamento civil entre homossexuais.

\footnotetext{
${ }^{58}$ STF, ADPF 132, Rel. Min. Ayres Britto, Distrito Federal, j. 05.05.2011.
} 
$\mathrm{O}$ referido diploma legal estabelece que " $\mathrm{O}$ casamento se realiza no momento em que o homem e a mulher manifestam, perante o juiz, a sua vontade de estabelecer vínculo conjugal, e o juiz os declara casados".

Mais uma vez, o embate ideológico girava em torno da interpretação do dispositivo. Segundo a opinião do setor conservador, que se apegava à interpretação literal, haveria expressa vedação ao casamento civil de pessoas do mesmo sexo. Por sua vez, os mais liberais, pautados na interpretação extensiva e sistemática, compreendiam que, não obstante o Código Civil tratasse de um homem e uma mulher, não estaria impedida a regulamentação do casamento homossexual.

Nessa perspectiva, no julgamento do REsp 1.183.378/RS, o Superior Tribunal de Justiça entendeu pela inexistência de vedação ao casamento civil entre pessoas do mesmo sexo, tendo por base o julgamento da ADPF 132 e da ADI 4.277. A decisão se transcreve abaixo:

DIREITO DE FAMÍLIA. CASAMENTO CIVIL ENTRE PESSOAS DO MESMO SEXO (HOMOAFETIVO). INTERPRETAÇÃO DOS ARTS. 1.514, $1.521,1.523,1.535$ e1.565 DO CÓDIGO CIVIL DE 2002. INEXISTÊNCIA DE VEDAÇÃO EXPRESSA AQUE SE HABILITEM PARA O CASAMENTO PESSOAS DO MESMO SEXO. VEDAÇÃOIMPLÍCITA CONSTITUCIONALMENTE INACEITÁVEL. ORIENTAÇÃOPRINCIPIOLÓGICA CONFERIDA PELO STF NO JULGAMENTO DA ADPF N. 132/RJ EDA ADI N. 4.277/DF.

1. Embora criado pela Constituição Federal como guardião do direitoinfraconstitucional, no estado atual em que se encontra a evolução do direito privado, vigorante a fase histórica da constitucionalização do direito civil, não é possível ao STJ analisar as celeumas que lhe aportam "de costas" para a Constituição Federal, sob pena de ser entregue ao jurisdicionado um direito desatualizado e sem lastro na Lei Maior. Vale dizer, o Superior Tribunal de Justiça, cumprindo sua missão de uniformizar o direito infraconstitucional, não pode conferir à lei uma interpretação que não seja constitucionalmente aceita.

2. O Supremo Tribunal Federal, no julgamento conjunto da ADPF n. 132/RJ e da ADI n. 4.277/DF, conferiu ao art. 1.723 do Código Civil de 2002 interpretação conforme à Constituição para dele excluir todo significado que impeça o reconhecimento da união contínua, pública e duradoura entre pessoas do mesmo sexo como entidade familiar, entendida esta como sinônimo perfeito de família. 
3. Inaugura-se com a Constituição Federal de 1988 uma nova fase do direito de família e, consequentemente, do casamento, baseada na adoção de um explícito poliformismo familiar em que arranjos multifacetados são igualmente aptos a constituir esse núcleo doméstico chamado "família", recebendo todos eles a "especial proteção do Estado". Assim, é bem de ver que, em 1988, não houve uma recepção constitucional do conceito histórico de casamento, sempreconsiderado como via única para a constituição de família e, por vezes, um ambiente de subversão dos ora consagrados princípios da igualdade e da dignidade da pessoa humana. Agora, a concepção constitucional do casamento diferentemente do que ocorria com os diplomas superados - deve ser necessariamente plural, porque plurais também são as famílias e, ademais, não é ele, o casamento, o destinatário final da proteção do Estado, mas apenas o intermediário de um propósito maior, que é a proteção da pessoa humana em sua inalienável dignidade.

4. O pluralismo familiar engendrado pela Constituição - explicitamente reconhecido em precedentes tanto desta Corte quanto do STF - impede se pretenda afirmar que as famílias formadas por pares homoafetivos sejam menos dignas de proteção do Estado, se comparadas com aquelas apoiadas na tradição e formadas por casais heteroafetivos.

5. O que importa agora, sob a égide da Carta de 1988, é que essas famílias multiformes recebam efetivamente a "especial proteção do Estado", e é tão somente em razão desse desígnio de especial proteção que a lei deve facilitar a conversão da união estável em casamento, ciente o constituinte que, pelo casamento, o Estado melhor protege esse núcleo doméstico chamado família.

6. Com efeito, se é verdade que o casamento civil é a forma pela qual o Estado melhor protege a família, e sendo múltiplos os "arranjos" familiares reconhecidos pela Carta Magna, não há de ser negada essa via a nenhuma família que por ela optar, independentemente de orientação sexual dos partícipes, uma vez que as famílias constituídas por pares homoafetivos possuem os mesmos núcleos axiológicos daquelas constituídas por casais heteroafetivos, quais sejam, a dignidade das pessoas de seus membros e o afeto.

7. A igualdade e o tratamento isonômico supõem o direito a ser diferente, o direito à auto-afirmação e a um projeto de vida independente de tradições e ortodoxias. Em uma palavra: o direito à igualdade somente se realiza com plenitude se é garantido o direito à diferença. Conclusão diversa também não se mostra consentânea com um ordenamento constitucional que prevê o princípio do livre planejamento familiar ( $\S 7^{\circ}$ do art. 226). E é importante ressaltar, nesse ponto, que o planejamento familiar se faz presente tão logo haja a decisão de duas pessoas em se unir, com escopo de constituir família, e desde esse momento a Constituição lhes franqueia ampla liberdade de escolha pela forma em que se dará a união.

8. Os arts. 1.514, 1.521, 1.523, 1.535 e 1.565, todos do Código Civil de 2002, não vedam expressamente o casamento entre pessoas do mesmo sexo, e não há como se enxergar uma vedação implícita ao casamento homoafetivo sem afronta a caros 
princípios constitucionais, como o da igualdade, o da não discriminação, o da dignidade da pessoa humana e os do pluralismo e livre planejamento familiar.

9. Não obstante a omissão legislativa sobre o tema, a maioria, mediante seus representantes eleitos, não poderia mesmo "democraticamente" decretar a perda de direitos civis da minoria pela qual eventualmente nutre alguma aversão. Nesse cenário, em regra é o Poder Judiciário - e não o Legislativo - que exerce um papel contramajoritário e protetivo de especialíssima importância, exatamente por não ser compromissado com as maiorias votantes, mas apenas com a lei e com a Constituição, sempre em vista a proteção dos direitos humanos fundamentais, sejam eles das minorias, sejam das maiorias. Dessa forma, ao contrário do que pensam os críticos, a democracia se fortalece, porquanto esta se reafirma como forma de governo, não das maiorias ocasionais, mas de todos.

10. Enquanto o Congresso Nacional, no caso brasileiro, não assume, explicitamente, sua coparticipação nesse processo constitucional de defesa e proteção dos socialmente vulneráveis, não pode o Poder Judiciário demitir-se desse mister, sob pena de aceitação tácita de um Estado que somente é "democrático" formalmente, sem que tal predicativo resista a uma mínima investigação acerca da universalização dos direitos civis.

\section{Recurso especial provido. ${ }^{59}$}

Diante do exposto, conclui-se que, após um longo histórico de preconceito e discriminação, a jurisprudência pátria vem exercendo papel fundamental no que se refere ao atendimento das demandas pleiteadas pelos homossexuais. Os julgados destacados solucionaram a insegurança jurídica fruto da omissão do legislador.

Vale destacar que as decisões proferidas em sede de controle abstrato possuem efeito vinculante em relação a todos os órgãos do Judiciário, bem como à administração pública direta e indireta, nas esferas municipal, estadual e federal, conforme se extrai da leitura do artigo 102 da Constituição Federal. Sendo assim, caminha-se para a progressiva inclusão social dos mais diversos grupos e para concretização dos ideais democráticos da igualdade, da cidadania e da liberdade.

\footnotetext{
${ }^{59}$ STJ, REsp 1.183.378/RS, Rel. Min. Luiz Felipe Salomão, Brasília, j. 25.10.2011.
} 


\title{
4.3 As famílias monoparentais
}

Conforme já exposto neste trabalho, a Constituição Federal retirou do instituto do casamento a exclusividade para formação de uma entidade familiar. A Lei Maior, no parágrafo $4^{\circ}$ do artigo 226, definiu como família a "comunidade familiar formada por qualquer dos pais e seus descendentes".

A família monoparental se faz cada vez mais presente na realidade social brasileira. Tendo em vista a inserção da mulher no mercado de trabalho, tornaram-se casa vez mais comuns as famílias formadas por apenas um dos pais e seus filhos. Tais entidades merecem especial proteção estatal, uma vez que, em geral, o genitor chefe da família, além de cuidar da prole, tem a incumbência de arcar com as despesas.

A monoparentalidade pode ser consequência de diversas situações fáticas. Destacam-se a viuvez, o divórcio, a adoção por pessoa solteira ou a inseminação artificial por mulher solteira. Todos esses paradigmas devem ser reconhecidos e protegidos pelo Estado, tendo em vista que, atualmente, o afeto é a estrutura basilar das famílias.

Segundo entendimento de Maria Berenice Dias, deve-se buscar alargar o conceito de família monoparental. Eis o entendimento da autora:

\begin{abstract}
A entidade familiar chefiada por algum parente que não um dos genitores, igualmente, constitui vínculo uniparental. Mesmo as estruturas de convívio constituídas por quem não seja parente, mas com crianças ou adolescentes sob sua guarda, podem receber a mesma denominação. Para ser configurar uma família como monoparental, basta haver diferença de gerações entre um de seus membros e os demais e desde que não haja relacionamento de ordem sexual entre eles. Mas não é a presença de menores de idade que permite o reconhecimento da família como monoparental. A maioridade dos descendentes não descaracteriza a monoparentalidade da família - é um fato social. ${ }^{60}$
\end{abstract}

O divórcio e a separação podem ser considerados as mais comuns causas geradoras da família monoparental. Após a separação dos cônjuges, é comum que o filho fique sob a guarda unilateral de um dos genitores, de modo que cabe ao outro o direito de visitar o menor. Embora o poder

\footnotetext{
${ }^{60}$ DIAS, 2011, p. 212-213.
} 
familiar continue sendo exercido por ambos os pais, verifica-se a presença da família monoparental, uma vez que o convívio com um dos ascendentes é muito mais acentuado, o qual se torna mais envolvido com a criação e formação do filho.

Além disso, consoante expressa autorização do Estatuto da Criança e do Adolescente, é juridicamente viável a adoção de um menor por parte de uma pessoa solteira. Assim como o casamento não é mais um requisito para constituição da família, a relação conjugal não é condição para a filiação.

Art. 25. Entende-se por família natural a comunidade formada pelos pais ou qualquer deles e seus descendentes.

Art. 42. Podem adotar os maiores de 18 (dezoito) anos, independentemente do estado civil. ${ }^{61}$

A adoção é guiada pelo princípio do melhor interesse da criança. Como se sabe, no Brasil, múltiplos são os casos de jovens que ficam instalados em abrigos à espera de um lar. Dessa forma, embora haja resistência à adoção por alguém solteiro, é preferível que se tenha somente uma pessoa para chamar de pai ou mãe do que nunca ter qualquer vínculo de filiação.

Como uma das grandes conquistas das famílias monoparentais, ressalta-se o moderno entendimento jurisprudencial no sentido de elevar o imóvel onde residem seus membros ao status de bem de família, respaldado juridicamente pela impenhorabilidade, não obstante esta seja composta apenas por um dos pais e seus descendentes. De acordo com a Súmula 364 do STJ, "o conceito de impenhorabilidade de bem de família abrange também o imóvel pertencente a pessoas solteiras, separadas e viúvas".

As famílias monoparentais, portanto, são a concretização do livre planejamento familiar, do princípio da igualdade, e da dignidade da pessoa humana, uma vez que não seria justo, em um Estado Democrático de

\footnotetext{
${ }^{61}$ BRASIL. [Estatuto da criança e do adolescente (1990)]. Lei n. 8.069, de 13 de julho de 1990.
} 
Direito, impedir o indivíduo de constituir uma família, pelo simples fato de não querer se casar ou estabelecer vínculos com outrem.

Com a elevação do livre planejamento familiar a direito constitucional (art. 227, $\$ 7^{\circ}, \mathrm{CF}$ ), não há como impedir que pessoas solteiras ou divorciadas constituam sua própria família, sua linha sucessória, inobstante o fato de não possuírem cônjuge ou companheiro.

\subsection{A pluriparentalidade e a vinculação socioafetiva}

A Constituição Federal de 1988, conforme abordado, foi responsável por abolir o tratamento discriminatório entre os filhos, com a supressão da classificação binária entre filiação legítima e ilegítima. Desse modo, a Lei Maior não elenca o vínculo biológico como único capaz de constituir uma entidade familiar.

Da análise dos artigos 227, parágrafo $6^{\circ}$ da CF/88 e 1.596 do Código Civil, depreende-se que a relação de parentalidade prescinde do liame biológico, como decorrência do princípio da afetividade, constitucionalmente estabelecido, o qual deve servir de paradigma para o Direito das Famílias.

A filiação socioafetiva não está calcada no quesito genético, mas sim na manifestação volitiva autônoma de estabelecer um vínculo entre pai e filho, com a observância dos deveres de respeito e assistência inerentes a tal condição. Esse ato de vontade deve ser exercido cotidianamente, de forma pública, de maneira que, assim, superam-se tanto a verdade biológica como as presunções jurídicas.

Considera-se, nesse esteio, como pai, aquele que assume a função paterna, consistente no oferecimento de abrigo, educação, carinho e assistência - não só material, mas, sobretudo, emocional. Tal relação não se escora na ascendência genética, haja vista essa ser um mero efeito da natureza, caso desatrelada do afeto e da convivência. 
Nessa perspectiva, a filiação socioafetiva não se limita à adoção, de modo que pode decorrer de outras relações de parentesco, como a de avós, tios, além de outras de natureza distinta. O importante, frise-se, é a verificação da consolidação de um vínculo afetivo. Constata-se, portanto, a evolução do ordenamento jurídico pátrio, uma vez que o vínculo paternofilial não se encontra adstrito a heranças genéticas e à transmissão de caracteres.

Ressalta-se que, após estabelecida a filiação socioafetiva, não pode aquele que se comportou como pai alegar superveniente rompimento do laço afetivo com o filho, a fim de se eximir do reconhecimento da filiação. De igual modo, não pode se escusar de seus encargos com fulcro em tal circunstância fática. Nesse sentido, eis os ensinamentos de Christiano Chaves de Farias:

O laço socioafetivo depende, por óbvio, da comprovação da convivência respeitosa, pública e firmemente estabelecida. Todavia, não é preciso que o afeto esteja presente no instante em que é discutida a filiação em juízo. Não raro, quando se chega às instâncias judiciais, é exatamente porque o afeto cessou, desapareceu, por diferentes motivos (não sendo razoável discuti-los). O importante é provar que o afeto esteve presente durante a convivência, que o afeto foi o elo que entrelaçou aquelas pessoas ao longo de suas existências. Equivale a dizer: que a personalidade do filho foi formada sobre aquele vínculo afetivo, mesmo que, naquele exato instante, não exista mais. Aqui calha, com precisão, o exemplo da adoção à brasileira, em que uma pessoa registra como seu filho um estranho e, depois de anos de afeto e de um cotidiano como pai e filho, quer negar a relação filiatória por algum motivo. Mesmo cessado o afeto em determinado momento, nesse caso, a filiação se estabeleceu pelo critério afetivo, que deve ser reconhecido pelo juiz. ${ }^{62}$

Uma vez estabelecida a filiação com fulcro na afetividade, ao filho decorrem automaticamente os direitos existenciais e patrimoniais. Tal como o filho biológico, o socioafetivo fará jus aos alimentos e à herança, além de ficar respaldado pelo poder familiar do pai afetivo, a quem caberá a incumbência de suprir as necessidades materiais e psicológicas.

Inobstante a proteção jurídica conferida à filiação socioafetiva, não se pode negar a ninguém o direito de conhecer sua ancestralidade genética.

\footnotetext{
${ }^{62}$ FARIAS; ROSENVALD, 2015, p. 594.
} 
Desse modo, é possível ao filho, a qualquer tempo, mover ação judicial de investigação de paternidade, a fim de saber qual sua origem biológica. Ressalta-se que o direito personalíssimo de acesso à sua família sanguínea não afeta em nada os vínculos afetivos já firmados.

Dentro de tal perspectiva, configura-se o choque entre a vinculação biológica e a sociafetiva, o qual mereceu especial atenção da jurisprudência pátria. Nessa linha de raciocínio, os tribunais vêm se orientando no sentido de afastar a possibilidade de uma superveniente investigação biológica de paternidade ter o condão de destituir um vínculo de filiação socioafetiva já estabelecido e consolidado perante a sociedade. Tem-se, como escopo, priorizar o princípio da afetividade em detrimento da verdade real, tendo em vista o melhor interesse da criança.

Nessa seara, merece destaque o recente entendimento proferido pelo Supremo Tribunal Federal, no julgamento do Recurso Extraordinário 898.060/SC, o qual solucionou a colisão existente entre o vínculo biológico e o socioafetivo, ao trazer uma resposta revolucionária para a questão.

EMENTA: RECURSO EXTRAORDINÁRIO. REPERCUSSÃO GERAL RECONHECIDA. DIREITO CIVIL E CONSTITUCIONAL. CONFLITO ENTRE PATERNIDADES SOCIOAFETIVA E BIOLÓGICA. PARADIGMA DO CASAMENTO. SUPERAÇÃO PELA CONSTITUIÇÃO DE 1988. EIXO CENTRAL DO DIREITO DE FAMÍLIA: DESLOCAMENTO PARA O PLANO CONSTITUCIONAL. SOBREPRINCÍPIO DA DIGNIDADE HUMANA (ART. $1^{\circ}$, III, DA CRFB). SUPERAÇÃO DE ÓBICES LEGAIS AO PLENO DESENVOLVIMENTO DAS FAMÍLIAS. DIREITO À BUSCA DA FELICIDADE. PRINCÍPIO CONSTITUCIONAL IMPLÍCITO. INDIVÍDUO COMO CENTRO DO ORDENAMENTO JURÍDICO-POLÍTICO. IMPOSSIBILIDADE DE REDUÇÃO DAS REALIDADES FAMILIARES A MODELOS PRÉ-CONCEBIDOS. ATIPICIDADE CONSTITUCIONAL DO CONCEITO DE ENTIDADES FAMILIARES. UNIÃO ESTÁVEL (ART. 226, § $3^{\circ}$, CRFB) E FAMÍLIA MONOPARENTAL (ART. 226, § $4^{\circ}$, CRFB). VEDAÇÃO À DISCRIMINAÇÃO E HIERARQUIZAÇÃO ENTRE ESPÉCIES DE FILIAÇÃO (ART. 227, § $6^{\circ}$, CRFB). PARENTALIDADE PRESUNTIVA, BIOLÓGICA OU AFETIVA. NECESSIDADE DE TUTELA JURÍDICA AMPLA. MULTIPLICIDADE DE VÍNCULOS PARENTAIS. RECONHECIMENTO CONCOMITANTE. POSSIBILIDADE. PLURIPARENTALIDADE. PRINCÍPIO DA PATERNIDADE RESPONSÁVEL (ART. 226, § $7^{\circ}$, CRFB). RECURSO A QUE SE NEGA PROVIMENTO. FIXAÇÃO DE TESE PARA APLICAÇÃ̃O A CASOS SEMELHANTES. 
1. O prequestionamento revela-se autorizado quando as instâncias inferiores abordam a matéria jurídica RECURSO EXTRAORDINÁRIO 898.060 SÃO PAULO RELATOR: MIN. LUIZ FUX RECTE.(S) :A. N. ADV.(A/S) :RODRIGO FERNANDES PEREIRA RECDO.(A/S) :F. G.

2. invocada no Recurso Extraordinário na fundamentação do julgado recorrido, tanto mais que a Súmula n. 279 desta Egrégia Corte indica que o apelo extremo deve ser apreciado à luz das assertivas fáticas estabelecidas na origem. 2. A família, à luz dos preceitos constitucionais introduzidos pela Carta de 1988, apartou-se definitivamente da vetusta distinção entre filhos legítimos, legitimados e ilegítimos que informava o sistema do Código Civil de 1916, cujo paradigma em matéria de filiação, por adotar presunção baseada na centralidade do casamento, desconsiderava tanto o critério biológico quanto o afetivo.

3. A família, objeto do deslocamento do eixo central de seu regramento normativo para o plano constitucional, reclama a reformulação do tratamento jurídico dos vínculos parentais à luz do sobreprincípio da dignidade humana (art. $1^{\circ}$, III, da CRFB) e da busca da felicidade. 4. A dignidade humana compreende o ser humano como um ser intelectual e moral, capaz de determinar-se e desenvolver-se em liberdade, de modo que a eleição individual dos próprios objetivos de vida tem preferência absoluta em relação a eventuais formulações legais definidoras de modelos preconcebidos, destinados a resultados eleitos a priori pelo legislador. Jurisprudência do Tribunal Constitucional alemão (BVerfGE 45, 187). 5. A superação de óbices legais ao pleno desenvolvimento das famílias construídas pelas relações afetivas interpessoais dos próprios indivíduos é corolário do sobreprincípio da dignidade humana. 6. O direito à busca da felicidade, implícito ao art. $1^{\circ}$, III, da Constituição, ao tempo que eleva o indivíduo à centralidade do ordenamento jurídico-político, reconhece as suas capacidades de autodeterminação, autossuficiência e liberdade de escolha dos próprios objetivos, proibindo que o governo se imiscua nos meios eleitos pelos cidadãos para a persecução das vontades particulares. Precedentes da Suprema Corte dos Estados Unidos da América e deste Egrégio Supremo Tribunal Federal: RE 477.554-AgR, Rel. Min. Celso de Mello, DJe de 26/08/2011; ADPF 132, Rel. Min. Ayres Britto, DJe de 14/10/2011. 7. O indivíduo jamais pode ser reduzido a mero instrumento de consecução das vontades dos governantes, por isso que o direito à busca da felicidade protege o ser humano em face de tentativas do Estado de enquadrar a sua realidade familiar em modelos pré-concebidos pela lei. 8. A Constituição de 1988, em caráter meramente exemplificativo, reconhece como legítimos modelos de família independentes do casamento, como a união estável (art. 226, $\S 3^{\circ}$ ) e a comunidade formada por qualquer dos pais e seus descendentes, cognominada "família monoparental" (art. 226, $\S 4^{\circ}$ ), além de enfatizar que espécies de filiação dissociadas do matrimônio entre os pais merecem equivalente tutela diante da lei, sendo vedada discriminação e, portanto, qualquer tipo de hierarquia entre elas (art. 227, § $6^{\circ}$ ). 9. As uniões estáveis homoafetivas, consideradas pela jurisprudência desta Corte como entidade familiar, conduziram à imperiosidade da interpretação não reducionista do conceito de família como instituição que também se forma por vias distintas do casamento civil (ADI n ${ }^{\circ}$. 4.277, Relator(a): Min. AYRES BRITTO, Tribunal Pleno, julgado em 05/05/2011). 10. A compreensão jurídica cosmopolita das famílias exige a ampliação da tutela normativa a todas as formas pelas quais a parentalidade pode se manifestar, a saber: (i) pela presunção decorrente do casamento ou outras hipóteses legais, (ii) pela descendência biológica ou 4 (iii) pela afetividade. 11. A evolução científica responsável pela popularização do 
exame de DNA conduziu ao reforço de importância do critério biológico, tanto para fins de filiação quanto para concretizar o direito fundamental à busca da identidade genética, como natural emanação do direito de personalidade de um ser. 12. A afetividade enquanto critério, por sua vez, gozava de aplicação por doutrina e jurisprudência desde o Código Civil de 1916 para evitar situações de extrema injustiça, reconhecendo-se a posse do estado de filho, e consequentemente o vínculo parental, em favor daquele utilizasse o nome da família (nominatio), fosse tratado como filho pelo pai (tractatio) e gozasse do reconhecimento da sua condição de descendente pela comunidade (reputatio). 13. A paternidade responsável, enunciada expressamente no art. $226, \S 7^{\circ}$, da Constituição, na perspectiva da dignidade humana e da busca pela felicidade, impõe o acolhimento, no espectro legal, tanto dos vínculos de filiação construídos pela relação afetiva entre os envolvidos, quanto daqueles originados da ascendência biológica, sem que seja necessário decidir entre um ou outro vínculo quando o melhor interesse do descendente for o reconhecimento jurídico de ambos. 14. A pluriparentalidade, no Direito Comparado, pode ser exemplificada pelo conceito de "dupla paternidade" (dual paternity), construído pela Suprema Corte do Estado da Louisiana, EUA, desde a década de 1980 para atender, ao mesmo tempo, ao melhor interesse da criança e ao direito do genitor à declaração da paternidade. Doutrina. 15. Os arranjos familiares alheios à regulação estatal, por omissão, não podem restar ao desabrigo da proteção a situações de pluriparentalidade, por isso que merecem tutela jurídica concomitante, para todos os fins de direito, os vínculos parentais de origem afetiva e biológica, a fim de prover a mais completa e adequada tutela aos sujeitos envolvidos, ante os princípios constitucionais da dignidade da pessoa humana (art. $1^{\circ}$, III) e da paternidade responsável (art. 226, $\S 7^{\circ}$ ). 16. Recurso Extraordinário a que se nega provimento, fixando-se a seguinte tese jurídica para aplicação a casos semelhantes: "A paternidade socioafetiva, declarada ou não em registro público, não impede o reconhecimento do vínculo de filiação concomitante baseado na origem biológica, com todas as suas consequências patrimoniais e extrapatrimoniais". ${ }^{63}$

No caso em análise, conquanto tenham existido votos divergentes, foi sedimentado pelo Supremo Tribunal Federal o entendimento segundo o qual a paternidade socioafetiva, declarada ou não em registro público, não impede o reconhecimento concomitante do vínculo biológico, com os efeitos jurídicos próprios.

Por meio do histórico julgamento, admitiu-se a possibilidade de acrescentar o nome do pai biológico da requerente ao registro, sem, contudo, surprimir seus avós paternos do referido documento, os quais foram responsáveis por registrá-la, logo após o nascimento.

Embora despida de origem biológica, a filiação socioafetiva é uma situação fática que merece respaldo jurídico, tendo como principal

\footnotetext{
${ }^{63}$ STF, RE 898.060/SC, Rel. Min. Luiz Fux, Distrito Federal, j. 22.09.2016.
} 
fundamental a cláusula geral de proteção da dignidade humana, que concentra na filiação um atributo essencial de constituição da identidade do indivíduo, sobretudo nos primeiros anos de vida.

Desconstituir o reconhecimento de uma relação de filiação calcada no afeto poderia causar diversos malefícios, como extirpar da criança ou adolescente aspecto crucial na formação de sua identidade e definição de sua personalidade. A identidade da pessoa, como direito fundamental, é insuscetível de ficar à mercê de conflitos familiares ou da tentativa de se encaixar uma realidade fática a um engessado paradigma projetado pelo ordenamento jurídico.

Em relação ao julgamento do Recurso Extraordinário acima exposto, merecem destaque os comentários de Flávio Tartuce:

\begin{abstract}
Como impactos iniciais, tal decisum traz três consequências que merecem destaque. A primeira delas é o reconhecimento expresso, o que foi feito por vários Ministros, no sentido de ser a afetividade um valor jurídico e um princípio inerente à ordem civil-constitucional brasileira. A segunda consequência, repisese, é a afirmação de ser a paternidade sociafetiva uma forma de parentesco civil (nos termos do art. 1.593, do CC), em situação de igualdade com a paternidade biológica. Em outras palavras, não há hierarquia entre uma ou outra modalidade de filiação, o que representa um razoável equilíbrio. A terceira consequência é a vitória da multiparentalidade, que passou a ser admitida pelo Direito brasileiro, mesmo que contra a vontade do pai biológico. ${ }^{64}$
\end{abstract}

À guisa de conclusão, tecem-se alguns esclarecimentos sobre o registro. Conforme previsão do artigo 1.603 do Código Civil de 2002, a filiação prova-se pela certidão do termo de nascimento registrada no Registro Civil. Conforme se extrai do referido dispositivo legal, não se exige comprovação de vínculo biológico para se efetuar o registro.

Com fulcro no artigo 1.604 do CC/02, ninguém pode vindicar estado contrário ao que resulta do registro de nascimento, salvo provando-se erro ou falsidade do registro. Contudo, após o julgamento do STF com repercussão geral, no que toca à socioafetividade, a regra, atualmente, é a multiparentalidade, de modo que, em sendo proposta uma ação pelo pai

\footnotetext{
${ }^{64}$ TARTUCE, 2017, p. 449.
} 
biológico para vindicar o filho e fazer constar seu nome em registro, não é necessário retirar o nome do pai registral. Torna-se juridicamente viável o duplo registro, constando tanto o pai socioafetivo como o genitor. 


\section{CONCLUSÃO}

Ao longo do presente trabalho, buscou-se traçar a transformação pela qual passou o Direito de Família. Não obstante os inúmeros desafios a serem enfrentados pela doutrina e jurisprudência, é notório o avanço do ordenamento pátrio, no sentido de abrir espaço para o reconhecimento de uma gama muito mais ampla de entidades familiares.

O instituto da família, que está em constante transformação, não pode ficar engessado a um conceito estático ou a um rol exemplificativo. Nesse sentido, mister se faz valorizar os recentes julgados dos Tribunais pátrios, os quais têm se apegado à livre escolha e a à busca da felicidade, em detrimento de formalismos legais.

Nessa perspectiva, papel crucial teve a Constituição Cidadã, uma vez que não se esmiuçou a fim de elencar todos os possíveis paradigmas familiares. Pelo contrário, estipulou um rol taxativo em seu artigo 226, de forma que a proteção estatal não deve se limitar à união estável, ao casamento e às famílias constituídas por apenas um dos pais.

Com o fenômeno da constitucionalização do Direito Civil, todos os institutos do Direito de Família devem ser interpretados à luz dos princípios constitucionais da dignidade da pessoa humana, da igualdade, da liberdade, do melhor interesse da criança e do adolescente, afetividade.

Constitui-se, assim, uma nova sistemática, tendo em vista a superação de óbices legais ao pleno desenvolvimento das famílias baseadas no afeto entre seus membros, as quais merecem integral amparo legal. Destacam-se como norteadores do Direito de Família o direito à busca da felicidade, que torna o indivíduo figura central do ordenamento jurídico, ao reconhecer as suas capacidades de autodeterminação e eleição dos próprios objetivos para realização pessoal. 
A Carta Magna de 1988 foi responsável por expandir os limites axiológicos presentes no conceito de família, cabendo ao Judiciário reconhecer novas entidades familiares, conforme surjam novas demandas sociais com pleitos legítimos. Desde que escoradas no afeto, na assistência, na solidariedade, no respeito, todas as formas de família merecem não só ser reconhecidas, mas também receber proteção estatal. 


\section{REFERÊNCIAS BIBLIOGRÁFICAS}

ADI 4.722, movida em face do artigo 1.723 do Código Civil de 2002.

BARROSO, Luís Roberto. Curso de Direito Constitucional Contemporâneo: Os conceitos fundamentais e a construção do novo modelo. $4^{a}$ ed. São Paulo: Ed Saraiva, 2013.

BRASIL. [Estatuto da criança e do adolescente (1990)]. Estatuto da criança e do adolescente: lei n. 8.069, de 13 de julho de 1990, e legislação correlata [recurso eletrônico]. - 9. ed. - Brasília: Câmara dos Deputados, Edições Câmara, 2010. 207 p. - (Série legislação; n. 83).

BRASIL. Art. 1.634. Lei n ${ }^{\circ}$ 10.406, de 10 de janeiro de 2002. Código Civil.

BRASIL. Constituição (1988). Constituição da República Federativa do Brasil. Brasília, DF, Senado, 1998.

BRASIL. Lei n ${ }^{\circ} 3.071$, de $1^{\circ}$ de janeiro de 1916. Código Civil (1916).

CATAlan, Marcos Jorge. Descumprimento Contratual - Modalidades, Consequências e Hipóteses de Exclusão do Dever de Indenizar. 1 ${ }^{a}$. Curitiba: Juruá, 2005.

DIAS, Maria Berenice. Manual de Direito das Famílias. $8^{\text {a }}$ ed. rev., atual. eampl. São Paulo: Editora Revista dos Tribunais, 2011.

DINIZ, Maria Helena. Dicionário Jurídico. v. 3. São Paulo: Ed. Saraiva, 1998. p.

FARIAS, Cristiano Chaves de; ROSENVALD, Nelson. Direitos Reais. Direito Civil: Famílias. 7ª ed. Rio de Janeiro: Editora Atlas, 2015.

GAMA, Guilherme Calmon Nogueira da. Princípios constitucionais de direito de família: guarda compartilhada à luz da lei $\mathrm{n}^{\circ}$ 11.698/08: família, criança, adolescente e idoso. São Paulo: Atlas, 2008.

I JORNADA DE DIREITO CIVIL. Enunciado 103. Brasília, 2003. 
LÔBO, Paulo. Direito Civil: Famílias. 6ª ed. São Paulo: Saraiva, 2015.

MADALENO, Rolf. Curso de Direito de Família. $6^{\mathrm{a}}$ ed. Rev., Atual. Eampl. Rio de Janeiro: Forense, 2015.

MADALENO, Rolf. Curso de Direito de Família. Rio de Janeiro: Forense, 2008.

PEREIRA, Caio Mário da Silva. Instituições de Direito Civil. Rio de Janeiro: Forense, 2013.

SAlOMÃO, Luis Felipe. Direito Privado: Teoria e Prática. $2^{\mathrm{a}}$ ed. Rev. Atual. Eampl. Rio de Janeiro: Forense, 2014.

STF, ADI 4.277, Rel. Min. Ayres Britto, Distrito Federal, j. 05.05.2011.

STF, ADIN 4.277 e ADPF 132, Rel. Min. Ayres Britto, Distrito Federal, j. 05.05.2011.

STF, ADPF 132, Rel. Min. Ayres Britto, Distrito Federal, j. 05.05.2011.

STF, RE 898.060/SC, Rel. Min. Luiz Fux, Distrito Federal, j. 22.09.2016.

STJ, EDcl. no REsp 1.026.981, 3 $3^{\mathrm{a}}$ Turma, Rel. Min. Nancy Andrighi, Distrito Federal, j. 04.08.2010.

STJ, EREsp. 182.223/SP, Corte Especial, Rel. Min. Sálvio de Figueiredo Teixeira, São Paulo, j. 06.02.2002.

STJ, REsp. 1.126.173, $3^{\text {a }}$ Turma, Rel. Min. Ricardo Villas Bôas Cueva, Minas Gerais, j. 09.04.2013.

STJ, REsp. 1.159.242/SP, $3^{\text {a }}$ Turma, Rel. Min. Nancy Andrighi, São Paulo, j. 24.04.2012, Dje 10.05.2012.

STJ, REsp. 1.183.378/RS, Rel. Min. Luiz Felipe Salomão, Brasília, j. 25.10.2011. 
STJ, REsp. 847.597/SC, $3^{\mathrm{a}}$ Turma, Rel. Min. Humberto Gomes de Barros, j. 06.03.2008.

STJ, REsp. 1.025.769/MG, Rel. Min. Nancy Andrighi, j. 24.08.2010.

TARTUCE, Flávio. Direito Civil: Direito de Família. $5^{\mathrm{a}}$ ed. Editora Forense, 2017. 